\title{
Lagoon Resident Fish Species of Conservation Interest According to the Habitat Directive (92/43/CEE): A Review on Their Potential Use as Ecological Indicator Species
}

\author{
Chiara Facca *(D), Francesco Cavraro, Piero Franzoi and Stefano Malavasi \\ Department of Environmental Sciences, Informatics and Statistics, Ca' Foscari University of Venice, \\ via Torino 155, 30175 Venice, Italy; cavraro@unive.it (F.C.); pfranzoi@unive.it (P.F.); mala@unive.it (S.M.) \\ * Correspondence: facca@unive.it; Tel.: +39-(0)-41-234-7733
}

Received: 22 May 2020; Accepted: 17 July 2020; Published: 20 July 2020

\begin{abstract}
Transitional waters are fragile ecosystems with high ecological, social and economic values, that undergo numerous threats. According to the information provided by European Member States in the framework of the European Directive 92/43/EEC (Habitat Directive), the main threat to these ecosystems is represented by morphological and hydrological changes. The present work focuses on six lagoon fish species included in the Habitat Directive annex II (species requiring conservation measures: Aphanius fasciatus, A. iberus, Knipowitschia panizzae, Ninnigobius canestrinii, Valencia hispanica and $V$. letourneuxi) that spend their entire life cycle in the Mediterranean priority habitat $1150^{*}$ "Coastal lagoons". The overview of the current scientific literature allowed us to highlight how the presence and abundance of these species may provide important indications on the conservation status of coastal lagoon habitats. In fact, their occurrence, distribution and biology depend on the presence of peculiar structures, such as salt marshes, small channels, isolated pools and oligohaline areas. Coastal lagoon fragmentation and habitat loss have led to a significant reduction in genetic diversity or local population extinction. Although Aphanius and gobies have been shown to survive in eutrophic environments, it is clear that they cannot complete their life cycle without salt marshes (mainly Aphanius) and wetland areas (mainly gobies).
\end{abstract}

Keywords: coastal lagoon; morphological alterations; habitat conservation; killifishes; gobies; Mediterranean Sea

\section{Introduction}

In 1992, the Directive 92/43/EEC, known as the Habitat Directive (HD), was issued to promote the "conservation of natural habitats and of wild fauna and flora" by ensuring bio-diversity (HD art. 2 par. 1) in the territory of European Member States. In Annex I, the Habitat Directive lists the sites of community interest, "whose conservation requires the designation of special areas of conservation". Among these sites, some are considered of "priority interest" because they are in danger of disappearance, such as the priority habitat $1150 *$ "Coastal lagoons", defined as follows:

"Lagoons are expanses of shallow coastal saltwater, of varying salinity and water volume, wholly or partially separated from the sea by sand banks or shingle, or, less frequently, by rocks. Salinity may vary from brackish water to hypersalinity depending on rainfall, evaporation and through the addition of fresh seawater from storms, temporary flooding of the sea in winter or tidal exchange" [1].

These habitats are found along all European coasts and their extent in the Mediterranean Sea varies widely, from 2 ha of Chalikiopoulou Greek lagoon [2] to 57,000 ha of Italian lagoon of Venice. 
In the Mediterranean biogeographic region (Table 1; Portugal excluded because it overlooks the Atlantic Ocean), there are 312 coastal lagoons included in the Natura 2000 network (the ecological network of sites to promote restoration and protection projects, in accordance with the HD's objectives, art. 3) [3] and, on average, their conservation status is unfavourable/bad (U2) [4]. The threats and pressures determining this evaluation are numerous and they can be linked both to the direct economic development of coastal areas (D03, E01, F02, J02) and to the effects of indirect activities that take place in the continental area (A02, A08; Table 2). These habitats, in fact, receive river inputs, enriched with nutrients and pollutants, leading to a substantial alteration of ecological balances and a general impairment of water quality [5]. However, the main threat is the direct destruction or reduction of habitats, due to the construction of infrastructure (e.g., ports), dredging of shipping channels and the creation of facilities for the regulation of hydrodynamism. Other threats include fishing, aquaculture, recreational development and the voluntary or accidental introduction of alien species, that has induced significant changes in environmental and ecological status [5]. From a management point of view, in almost all Member States, coastal lagoons are public property, except for a few special cases where some confined portions are privately managed [2].

Table 1. Number of "Coastal lagoons" (habitat code 1150*) in the Natura 2000 Network for EU Member States in the Mediterranean biogeographic region (Portugal excluded). Data were elaborated by consulting [3].

\begin{tabular}{cc}
\hline $\begin{array}{c}\text { EU Member State in } \\
\text { Mediterranean Region }\end{array}$ & $\begin{array}{c}\text { Number of Natura 2000 Sites as Coastal Lagoon } \\
\text { (HD Code 1150*) }\end{array}$ \\
\hline Republic of Cyprus (CY) & 1 \\
Croatia (HR) & 21 \\
France (FR) & 34 \\
Greece (GR) & 41 \\
Italy (IT) & 147 \\
Malta (MT) & 4 \\
Slovenia (SI) & 2 \\
Spain (ES) & 62 \\
\hline TOTAL & 312 \\
\hline
\end{tabular}

Table 2. Activities with highly important pressures and threats on "coastal lagoons" habitats throughout the EU. The "Pressures" and "Threats" columns show the number of Member States that have reported these activities as the ten most impacting (modified from the global report for the 2007-2012 reporting period for coastal lagoons [4]).

\begin{tabular}{cccc}
\hline Code & Activity & Pressures & Threats \\
\hline J02 & Changes in water bodies conditions & 21 & 22 \\
H01 & Pollution to surface waters & 16 & 9 \\
E03 & Discharges (household/industrial) & 7 & 7 \\
F02 & Fishing and harvesting aquatic resources & 7 & 7 \\
A08 & Fertilisation in agriculture & 5 & 5 \\
H02 & Pollution to groundwater & 5 & 5 \\
K02 & Vegetation succession/Biocenotic evolution & 5 & 7 \\
A02 & Modification of cultivation practices & 4 & \\
E01 & Urbanisation and human habitation & 4 & 7 \\
H03 & Pollution to marine waters & 4 & \\
L07 & Storm, cyclone & & 5 \\
D03 & Shipping lanes and ports & & 4 \\
\hline
\end{tabular}

From morphological and hydrodynamic points of view, each lagoon has peculiar characteristics closely related to the amount of freshwater inputs, tidal fluctuations and human interventions that, very often, have modified these areas either by land reclamation or by exploitation of fish resources 
or for navigation. The composite mosaic of the lagoon structure, with islands, sand barriers, salt marshes, wetlands, etc., determines a high heterogeneity from which we can derive the ability to support higher productivity, compared to adjacent seas. These characteristics, determined by the transition between continental and marine environments, may also favour the presence of endemic species of both freshwater and marine fauna [6].

However, not all organisms can tolerate these marked physio-chemical, spatial and temporal variations, so the biodiversity can be lower than that in the adjacent sea and freshwaters, because of the reduced euryvalence of most species. Among fish fauna, species can be categorized into functional guilds on the basis of the way they use transitional areas: to breed, to feed, as a nursery for juveniles, as refuge, as migratory routes between freshwaters and seas, for the entire life cycle [7-9].

The Annex II of HD includes "Animal and Plant Species of Community Interest whose conservation requires the designation of special conservation zones". Among these, more than 60 fish species are listed, including bony fishes and cyclostomes. Focusing the attention on the species recorded in the "Coastal Lagoon" habitats of the Mediterranean Sea, on the basis of data provided by Member States [3], it was possible to fill the list in Table 3 [3,10-14], further completed with the information on the Conservation status under the Habitat Directive and the red list assessments compiled by the International Union for the Conservation of Nature (IUCN) [13]. This list includes 26 species that could be grouped in functional guilds, according to the classification proposed by Potter et al. [9]: anadromous fishes (five species), freshwater fishes (17 species) and lagoon residents (four species). The present review aims at exploring the potential use of fish species of Community interest (sensu Habitat Directive art. 4, letter g), as indicators in the context of lagoon coastal habitats.

Ecological indicator species are defined as species whose presence and abundance provide information about ecosystems [15]. As the morphological alteration is one of the main threats for coastal lagoons (Table 2, [4]), the present paper describes the biology, habitat preference, distribution and conservation status of those fish species that are more strictly related to salt marshes and wetlands, in order to propose them as early warning signal of habitat loss. Bortone et al. [16] indicates that the guild of estuarine resident is the most suitable to be used as an indicator of lagoon environmental conditions. Therefore, four lagoon resident species (Table 3), that spend their entire life cycle in a transitional environment, were selected. Adapted to a naturally stressed ecosystem, these species can tolerate wide environmental variations and, hence, cannot be considered indicators of water quality. However, in the following sections, examples on how these species can be threatened by the loss or alteration of peculiar habitat structures will demonstrate their suitability as indicators. In this document, the term "ecological indicators" means the indicators that respond to environmental stressors related to changes in the structure of lagoon habitats, including morphological alterations, salinity changes, and presence of invasive alien species.

In the Habitat Directive, Aphanius fasciatus and A. iberus are referred to as belonging to the order Atheriniformes, family Cyprinodontidae, but the recent nomenclature places them in the order Cyprinodontiformes and the family is Aphaniidae [17]. Similarly, Knipowitschia panizzae and Ninnigobius (former Pomatoschistus) canestrinii are listed as Perciformes, family Gobiidae, while are now attributed to the order Gobiiformes, family Gonionellidae [12]. The most common species for the number of reports in the Mediterranean coastal lagoons of the Natura 2000 Network is A. fasciatus (109 sites), while the others are present in 20-30 sites (Table 3). None of these species are priority species, meaning a species "for the conservation of which the Community has particular responsibility in view of the proportion of their natural range" (HD art. 1 letter h) nor is present in other Annexes. Additionally, the two species belonging to the genus Valencia were discussed, since they are phylogenetically related to Aphanidae and have a high level of conservation priority. Moreover, $V$. hispanica and V. letourneuxi occur in small coastal lakes, tolerating low salinity conditions, and the former shares the endemic status with $A$. iberus along the Mediterranean Spanish coast. 
Table 3. List of fish species in Habitat Directive's Annex II and their presence in the habitats 1150* Coastal lagoons in the Mediterranean Sea basin. The first column included the species as listed in HD, and the second column the currently accepted nomenclature, verified by consulting [10-12]. IUCN category abbreviations as follow: DD-Data deficient; LC-Least concern; NT-Near Threatened; VU-Vulnerable; EN-Endangered; CR-Critically Endangered; NA-Not Assessed. Conservation status abbreviations as follow: FV-Favourable; U1-Unfavourable/Inadequate; U2-Unfavourable/Bad; XX-unknown. The abbreviations for the Member States are shown in Table 1. The asterisk $\left(^{*}\right)$ indicates that the species is a priority species; $(\mathrm{o})$ indicates species that are neither in Annex IV nor V; (V) indicates the species that are also in Annex V, but not in Annex IV. Species highlighted in grey are particularly related to Coastal lagoon conservation status. Data were elaborated by consulting [3,13,14].

\begin{tabular}{|c|c|c|c|c|c|c|c|c|c|c|c|c|c|}
\hline $\begin{array}{l}\text { Name of the Species } \\
\text { in Annex II }\end{array}$ & $\begin{array}{l}\text { Name of the Species } \\
\text { Currently Accepted }\end{array}$ & $\begin{array}{l}\text { Functional } \\
\text { Group }\end{array}$ & IUCN & $\begin{array}{l}\text { Conservation } \\
\text { Status }\end{array}$ & $\mathrm{CY}$ & ES & FR & GR & HR & IT & MT & SI & Total \\
\hline \multicolumn{14}{|c|}{ PETROMYZONTIFORMES } \\
\hline \multicolumn{14}{|c|}{ Petromyzontidae } \\
\hline Lampetra fluviatilis (V) & Lampetra fluviatilis (V) & Anadromous & $\mathrm{LC}$ & $\mathrm{U} 2$ & & & 2 & & & 2 & & & 4 \\
\hline Petromyzon marinus (o) & Petromyzon marinus (o) & Anadromous & $\mathrm{LC}$ & $\mathrm{U} 2$ & & 1 & 4 & & 1 & 9 & & & 15 \\
\hline \multicolumn{14}{|c|}{ ACIPENSERIFORMES } \\
\hline \multicolumn{14}{|c|}{ Acipenseridae } \\
\hline * Acipenser naccarii & *Acipenser naccarii & Anadromous & $\mathrm{CR}$ & $x X$ & & & & & & 5 & & & 5 \\
\hline * Acipenser sturio & *Acipenser sturio & Anadromous & $\mathrm{CR}$ & $\mathrm{U} 2$ & & & & 1 & & & & & 1 \\
\hline \multicolumn{14}{|c|}{ CLUPEIFORMES } \\
\hline \multicolumn{14}{|c|}{ Clupeidae } \\
\hline Alosa fallax (V) & Alosa fallax (V) & Anadromous & LC & $\mathrm{U} 2$ & & 2 & 6 & 7 & 1 & 30 & & & 46 \\
\hline Alosa vistonica $(\mathrm{V})$ & Alosa vistonica $(\mathrm{V})$ & Freshwater & CR & $\mathrm{U} 2$ & & & & 1 & & & & & 1 \\
\hline \multicolumn{14}{|c|}{ SALMONIFORMES } \\
\hline \multicolumn{14}{|c|}{ Salmonidae } \\
\hline Salmo marmoratus (o) & Salmo marmoratus (o) & Freshwater & $\mathrm{LC}$ & $\mathrm{U} 2$ & & & & & 1 & & & & 1 \\
\hline \multicolumn{14}{|c|}{ CYPRINIFORMES } \\
\hline \multicolumn{14}{|c|}{ Cyprinidae } \\
\hline Alburnus albidus (o) & Alburnus albidus (o) & Freshwater & VU & U2 & & & & & 1 & 2 & & & 3 \\
\hline Aspius aspius (V) & Leuciscus aspius (V) & Freshwater & NA & $x X$ & & & & 2 & & & & & 2 \\
\hline Barbus meridionalis (V) & Barbus meridionalis (V) & Freshwater & NT & U1 & & 1 & 2 & & & & & & 3 \\
\hline Barbus plebejus (V) & Barbus plebejus (V) & Freshwater & $\mathrm{LC}$ & $x X$ & & & & & & 2 & & & 2 \\
\hline Chalcalburnus chalcoides (o) & Alburnus chalcoides (o) & Freshwater & $\mathrm{LC}$ & $X X$ & & & & 1 & & & & & 1 \\
\hline
\end{tabular}


Table 3. Cont.

\begin{tabular}{|c|c|c|c|c|c|c|c|c|c|c|c|c|c|}
\hline $\begin{array}{l}\text { Name of the Species } \\
\text { in Annex II }\end{array}$ & $\begin{array}{l}\text { Name of the Species } \\
\text { Currently Accepted }\end{array}$ & $\begin{array}{l}\text { Functional } \\
\text { Group }\end{array}$ & IUCN & $\begin{array}{l}\text { Conservation } \\
\text { Status }\end{array}$ & $\mathrm{CY}$ & ES & FR & GR & HR & IT & MT & SI & Total \\
\hline Chondrostoma soetta (o) & Chondrostoma soetta (o) & Freshwater & EN & $X X$ & & & & & & 2 & & & 2 \\
\hline Rhodeus sericeus amarus (o) & Rhodeus amarus (o) & Freshwater & $\mathrm{LC}$ & $X X$ & & & & 2 & & & & & 2 \\
\hline Rutilus pigus (V) & Rutilus pigus (V) & Freshwater & $\mathrm{LC}$ & $X X$ & & & & & & 2 & & & 2 \\
\hline Rutilus rubilio (o) & Sarmarutilus rubilio (o) & Freshwater & NT & U1 & & & & & & 2 & & & 2 \\
\hline & & & Cobitid & & & & & & & & & & \\
\hline Cobitis taenia $(\mathrm{o})$ & Cobitis taenia $(\mathrm{o})$ & Freshwater & $\mathrm{LC}$ & $X X$ & & 9 & & & 1 & & & & 10 \\
\hline Cobitis trichonica (o) & Cobitis trichonica (o) & Freshwater & EN & FV & & & & 1 & & & & & 1 \\
\hline \multicolumn{14}{|c|}{ SILURIFORMES } \\
\hline \multicolumn{14}{|c|}{ Siluridae } \\
\hline Silurus aristotelis $(\mathrm{V})$ & Silurus aristotelis (V) & Freshwater & $\mathrm{DD}$ & FV & & & & 1 & & & & & 1 \\
\hline \multicolumn{14}{|c|}{ SCORPAENIFORMES } \\
\hline \multicolumn{14}{|c|}{ Cottidae } \\
\hline Cottus gobio (o) & Cottus gobio (o) & Freshwater & LC & U1 & & & 1 & & & & & & 1 \\
\hline \multicolumn{14}{|c|}{ In directive annexes listed as ATHERINIFORMES, but currently accepted as CYPRINODONTIFORMES } \\
\hline \multicolumn{14}{|c|}{ In directive annexes listed as Cyprinodontidae, but currently accepted as Aphaniidae } \\
\hline Aphanius iberus (o) & Aphanius iberus (o) & Lagoon resident & EN & U1 & & 29 & & & & & & & 29 \\
\hline Aphanius fasciatus (o) & Aphanius fasciatus (o) & Lagoon resident & LC & U1 & & & 10 & 20 & 1 & 72 & 4 & 2 & 109 \\
\hline \multicolumn{14}{|c|}{ In directive annexes listed as Cyprinodontidae, but currently accepted as Valenciidae } \\
\hline * Valencia hispanica & *Valencia hispanica & Freshwater & CR & $\mathrm{U} 2$ & & 13 & & & & & & & 13 \\
\hline *Valencia letourneuxi & *Valencia letourneuxi & Freshwater & $\mathrm{CR}$ & U1 & & & & 2 & & & & & 2 \\
\hline \multicolumn{14}{|c|}{ In directive annexes listed as PERCIFORMES, but currently accepted as GOBIIFORMES } \\
\hline \multicolumn{14}{|c|}{ In directive annexes listed as Gobiidae, but currently accepted as Gobionellidae } \\
\hline Knipowitschia panizzae (o) & Knipowitschia panizzae (o) & Lagoon resident & $\mathrm{LC}$ & FV & & & & & 3 & 22 & & & 25 \\
\hline Pomatoschistus canestrinii (o) & Ninnigobius canestrinii (o) & Lagoon resident & $\mathrm{LC}$ & FV & & & & & 2 & 18 & & & 20 \\
\hline
\end{tabular}


Despite the different conservation status of these six species, on the basis of the official European and International documents, related to the Habitat Directive and IUCN red list, these species may represent ecological indicator species of the complex mosaic of habitats characterizing the coastal lagoons in the Circum-Mediterranean area. The first goal of the present review was to collect and present three main components of the knowledge available on these species, on the basis of the current scientific literature: (1) Biology and Distribution, including the main information on population ecology and genetics, behaviour and life history (2) Conservation status, providing useful data to obtain some insights on the estimated conservation status of these species across their geographical range of distribution (3) Management, that is, interventions and actions conducted on these species, in terms of habitat conservation and restoration, including all projects carried out until present to enhance the favourable conservation status of their population.

The second goal was to overview and comparatively analyse this information, not only to provide a state of the art on the Conservation Biology of these species, but also to identify the potential future directions of research that may promote the use of these species as ecological indicators of morphological alterations in Mediterranean transitional water systems.

\section{Aphanius Fasciatus (Valenciennes, 1821)—Order Cyprinodontiformes}

\subsection{Biology and Distribution}

Individuals of $A$. fasciatus are small in size (maximum total length of female approx. 8-9 cm [18]) and have a marked sexual dimorphism, with males being smaller than females, characterized by yellow to yellow/orange caudal, dorsal and anal fin coloration (in some specimens, a vertical black band can also be present on the caudal fin) and 10-12 transversal brown bands alternating with straighter, silver-white bands on a greenish brown body [18]; females have 11-17 short dark brown bands along both sides of the body and the background is grey. The life cycle can last at maximum six to seven years [18,19] but, generally, sexual maturity is achieved in the first year of age [19], favouring a large number of generations and a rapid turnover of the population [20]. Females are, generally, more abundant than males, although the sex ratio displays significant seasonal variations: males, with their brighter colours and striking courtship behaviour, could suffer a higher mortality during the reproductive period [18,21,22]. It is omnivorous [18] and its diet varies with individuals' age and seasons: juveniles are planktonophagic while adults become benthivores [23]. Although A. fasciatus can be found in freshwaters, especially in the terminal sections of rivers, the most abundant populations live in coastal environments from brackish [24] to hyperhaline water bodies [20,25], both closed or subjected to tidal excursions. It is supposed that the reproduction is synchronized with the moon phases because adults exploit the rising spring tide to reach the most isolated canals within the salt marsh system [26]. During the courtship, the male, trying to exclude the competitors, pushes the female towards the optimal area for spawning, which is represented by submerged vegetation in small and isolated creeks inside salt marsh system. Males have no territorial behaviour and parental cares lack, so the cannibalism of eggs often occurs [27]. After hatching, which takes place 14 days after the spawning, when the tide height is again favourable to movements, the juveniles reach small bodies of water, isolated from open waters at low tide and, therefore, they are less at risk of predation [26]. Field observations on the life cycle of this species suggest that it is a sedentary fish throughout all of the year, preferring isolated areas [24], well protected from predation, avoiding the open lagoon [28]. The limited home range, the large demersal eggs, the absence of larval dispersal stages $[19,21]$ and the fragmentation of brackish habitats lead to a genetic isolation with scarce gene flow [25] and a high degree of genetic divergence among populations [24], inducing some authors to hypothesize the presence (not verified) of different species within the complex A. fasciatus [20]. A marked genetic diversity among the populations of $A$. fasciatus has been observed in the east coast of the Adriatic Sea, where individuals of the saline in the Northern part were found to be genetically distinct from those in the south [29]. Likewise, populations from Sicilian, Sardinian and Adriatic coasts display 
significant osteological differentiation [30]. Bottleneck effects were documented in some Italian lagoons along the Tyrrhenian coast, where a high mortality rate due to particular events, such as dystrophic crises, significant tidal changes [31] or lack of maintenance in saltern environments [25], determined a dramatic genetic loss. However, except for these few documented cases, A. fasciatus populations are considered to be demographically stable, namely without recent founder events or recurrent bottlenecks [24]. In Italy, two main clusters were identified with a similar genetic structure: the first includes the Tyrrhenian populations above about latitude $41^{\circ} \mathrm{N}$ and the second the southern Tyrrhenian and the Adriatic ones [32].

A. fasciatus is one of the most eurythermal and euryhaline species of the Mediterranean Sea, being able to withstand temperature changes between 4 and $40{ }^{\circ} \mathrm{C}$ and to reproduce at a salinity between 10 and 80 [20]. Despite this high capacity to adapt to extreme physical-chemical conditions, the genetic variation within-population is very small and is threatened by natural and anthropogenic pressures [25,32]; coupling this with the scarce gene flow among populations [24], the species survival can be locally compromised [33]. This situation was reported in the Maltese island, where only four populations were found in hydrologically isolated sites [34]. Furthermore, these populations were highly vulnerable as the abundance of adults and the percentage of juvenile survival were low [35].

It is widely distributed along the coasts of central Mediterranean basin; in the easternmost coasts it is scarcely abundant because $A$. dispar is present, even if, in some Egyptian lagoons, both species have been reported and hybrids have been observed [33]. In the westernmost areas, only A. iberus has always been recorded. According to the Natura 2000 network dataset, A. fasciatus is present along all Italian and Greek coasts, in Malta, Croatia and Slovenia and along the Corsican coasts (Table 3).

\subsection{Conservation Status}

At the level of the Mediterranean Sea, it is estimated that there are 153 populations [36], and the species is reported at 137 Natura 2000 sites, of which 109 are priority coastal lagoon habitats. In Italy, populations are recovering and in good condition [33], but the state of conservation at the international level is considered unfavourable/inadequate, although the species is not at risk of threat [37].

According to Natura 2000 dataset (Table 3), in Italy, A. fasciatus is present in 72 coastal lagoons, with a heterogeneous distribution. The populations of the northern Adriatic Sea are distributed in the lagoon systems from the Isonzo estuary to the Pialassa lagoon and appear constant over time but distinct from each other [33,38], with a highly variable density; in fact, depending on the season and local morphological structures, the density can range, as in the case of the Venice lagoon, from $2 \mathrm{ind} / 100 \mathrm{~m}^{-2}$ in salt marsh areas strongly influenced by tides to $205 \mathrm{ind} / 100 \mathrm{~m}^{-2}$ in almost-closed artificial ditches [28]. In the southern Adriatic Sea, two distinct populations, one in the northern and the other in the southern Apulia zone, may be the result of channelling works that have fragmented the habitats and created inhospitable intermediate areas [33]. Along the Tyrrhenian coast, it is present in Tuscany and partially in Latium, and it is believed that the absence of $A$. fasciatus, between Latium and Campania, may be the consequence of extensive land reclamation conducted in the first half of the 20th century [33]. A. fasciatus surely disappeared from several inland waters, where it was reported in the 1800s and until 1980, and recently it has been observed only in Sicilian ones [33,39]. Past and present data on its distribution and abundance in rivers are scarce, but it is supposed that A. fasciatus, although it can survive in freshwaters, has little affinity for this habitat [33]. In fact, freshwaters host a more diverse community than brackish zones, where more constraining conditions limit the taxonomic richness [40], and A. fasciatus was demonstrated to suffer from the presence of other species and to prefer marginal and isolated zones [28,33]. Moreover, in recent years, the freshwater species Gambusia holbrooki (order Cyprinodontiformes, family Poeciliidae) has determined the extinction of some A. fasciatus populations in Northern Italian rivers [33,39]. This invasive species was demonstrated to be highly aggressive in oligohaline waters, but to be less successful at higher salinity [41,42], inducing species that can tolerate wide salinity variations to move towards brackish waters. 
Despite the reduction of the range in freshwaters, in the original brackish and coastal environments, there has been a recovery of $A$. fasciatus, with the reappearance of populations considered extinct, especially in the northern Tyrrhenian coast [33]. The factors favouring the recovery are unknown, but the most probable reason seems to be the reappearance of wetlands and the establishment of protected areas, including transitional water bodies [33].

In the Greek Porto Lagos lagoon, the relative abundance of $A$. fasciatus reached almost $10 \%$ of the ichthyofauna community, with catch per unit effort (CPUE) from 5 in May 1989 to 1572 in October 1989 [43]. More recent studies, also in other Greek lagoons, describe population dynamics and structure, but they do not report density or abundance data. However, considering the number of specimens caught during these studies, it can be supposed that the populations are rather abundant $[19,21,23]$.

In Cyprus Akrotiri wetlands, A. fasciatus was demonstrated to have a "contraction-expansion" distribution depending on the annual hydrology. Based on observations between 2008 and 2015, the species' range was significantly contracted and, in 2016, the CPUE ranged from 12 to 931 [44].

In Croatia, until the early 2000s, the species was reported in several sites, while more recently, it has been found only in half of the historical basins. However, some new findings were recorded and some other habitats have to be investigated. The data available indicate that the distribution is discontinuous along the entire eastern Adriatic coast and the captures tend to be rather low [45].

Depending on the colonization range, the main, but not unique, threats for A. fasciatus are:

1. in freshwaters, especially, competition with the invasive species G. holbrooki, which is particularly aggressive at low salinity values [42,44]. Despite the fact that $G$. holbrooki can be found also at high salinity, as for example in Mar Menor (Spain; [46]) and in some French lagoons [47], its metabolism is particularly affected by the necessity to maintain the osmotic equilibrium. The effects on the community structure are evident due to an increase of sex ratio (M/F): females have a lower survival rate being larger than male and having higher reproductive investment [41]; moreover, Alcaraz et al. [48] demonstrated that, at salinity 25, its behaviour is less aggressive and its predation capacity slower than that of $A$. fasciatus;

2. in hyperhaline systems, the heavy hydromorphological modifications related to the salt production and extraction and/or the lack of maintenance leading to habitat degradation and significant genetic loss [25];

3. in lagoon systems, the loss of habitat complexity structure due to erosive phenomena and the consequent disappearance of salt marshes that represent the preferred habitat for refuge, reproduction and growth of both adults and juveniles $[27,28,49]$.

\subsection{Management}

Some recent works were conducted to assess the ecological value of artificial habitats (ditches) for the species, with a view to manage and preserve these habitats as surrogates of saltmarsh areas [28,49]. In the Venice lagoon, abundant, well-structured, healthy and successful breeding populations were, in fact, observed in abandoned artificial ditches, once used for traditional fish farming, as small marinas or as a defence line during the two world wars [49]. These artificial ditches, located in marginal areas, completely isolated from the open lagoon, can offer protection from predators, high resources and determine different adaptive strategies. In the lagoon of Venice, it was observed that the populations of natural salt marshes had a higher mortality rate than those of artificial canals, in a probable relation with a higher predation pressure due to the presence of piscivore fishes. The different predatory pressure, combined also with a greater availability of food, has favoured the development of different life histories in the populations of artificial ditches, which live longer and invest more in growth and less in reproduction [28]. These artificial ditches can, therefore, be an important resource for the conservation of local populations, but it remains important to maintain natural ecosystems in their complexity. 
The strong sedentary behaviour of the species can seriously compromise its ability to adapt to environmental changes in response to human pressure, because the gene flow is reduced and it cannot guarantee a sufficient genetic variability $[24,25,32]$. On the other hand, the strong relationship with the habitat is an important feature when choosing the species as an indicator of habitat conservation status. Its survival and reproductive rate, in fact, depends on the possibility to find sheltered areas with low hydrodynamism. On the whole, the salt marsh structures with small tidal creeks and pools have to be maintained and protected from erosion processes but, at the same time, the connectivity among similar habitats has to be guaranteed, avoiding the fragmentation, due to land reclamation or to the construction of infrastructures or to the dredging of large and deep canals. Although sedentary, the connectivity between salt marsh areas or even lagoon systems may allow some small migrations and, hence, a better gene flow.

Considering the water quality of some habitats where the species is generally abundant, it does not seem necessary to pay particular attention to the trophic status, whereas heavy metals and organic pollutants seem to affect the reproduction [50] and to cause spinal deformities [51].

The mosaic of habitats occupied by the species should be investigated and managed also in relation to potential competition and distribution of G. holbrooki. Specific management actions to reduce the impact of $G$. holbrooki on A. fasciatus were not found, but some authors described how to intervene with other native species, mainly in freshwater habitats. An efficient management plan of interventions could require the following actions:

(i) actions aimed at decreasing the probability of habitat recolonization by Gambusia spp. from nearby locations, to avoid a rapid return of the species and, hence, the wastefulness of resources [52]. As an example, in the case of artificial, man-regulated habitats, the management of the water salinity could favour the autochthonous species survival and proliferation.

(ii) non-invasive eradication methods, although, to date, the only proven, cost-efficient eradication method is poisoning [52], but attention must be paid to the effect on native and non-target organisms. In any case, the eradication has to be scrupulously planned, because it can be more effective if it is carried out in area with limited probabilities of Gambusia's recolonization [52];

(iii) actions aimed at increasing the intra-guild predation. It was found that adults of some native species can prey on Gambusia's eggs and larvae [53]. Therefore, strengthening the native populations with the introduction of adult specimens may reduce Gambusia's density.

\section{Aphanius iberus (Valenciennes, 1846)—Order Cyprinodontiformes}

\subsection{Biology and Distribution}

A. iberus is an endemic species of the Mediterranean coasts of Spain, often abundant in salt flats and brackish waters, but, sometimes, also present in freshwaters. It has a short life cycle (about 2 years), but a rapid growth rate and strong interannual variability in recruitment [54]. Several morphotypes are recognized, but the degree of differentiation is similar to that of other species of the genus Aphanius. The male has bluish grey, olive to bluish green body [18] with narrow silvery cross bands that also extend to the tail fin; the female has an olive green or bluish body with small black spots that tend to form stripes, one of which overlaps the lateral line. Males are also on average smaller $(4.5 \mathrm{~cm})$ than females $(6.0 \mathrm{~cm})$. The sex ratio is rather variable, but, in general, females are more abundant, due to male mortality after spawning [18]. As for the diet, it is omnivorous, combining both animal (mainly crustaceans) and plant of detritic origin [55]; as a generalist, it could be able to survive even the severe changes suffered by estuarine and coastal habitats [56]. In fact, the diet may vary depending on the availability of prey and, although it is generally considered to be a benthivorous micropredator, close correlations with organisms in the water column have been observed, particularly in juveniles. When available, harpacticoid copepods are the dominant prey above all for smaller fish; larger fish tend to add some larger prey without completely changing the trophic niche and feeding habitat with growth [55]. A. iberus is a gonochoric species with a reproductive strategy typical of unstable 
environments, as it reaches sexual maturity early, already a few month-olds, investing a lot of energy. The period of spawning varies depending on the latitudes, between May and August in the Ebro Delta (Catalonia, Spain) [57] and until October/November to the south, in the Mar Menor (Murcia, Spain) [58]. In one season, multiple spawning events take place [57]. Spawning and egg hatching can occur at salinities between 5 and 60 and temperatures $22-28{ }^{\circ} \mathrm{C}$ [18]. Populations of $A$. iberus from two areas in Catalonia (Spain) $300 \mathrm{~km}$ apart displayed significant genetic divergences [18]. Moreover, the species of Aphanius of the Atlantic coast of Spain, following genetic studies, has been recognized as A. baeticus and not as A. iberus [57].

\subsection{Conservation Status}

Along the Spanish coast, seven operational conservation units (OCUs) were distinguished with an overall low gene diversity [59]. The degree of isolation of populations is very high and it was observed that small-sized A. iberus can have a really restricted home range (approx. $250 \mathrm{~m}$ ) [48]. The high sedentary behaviour has been accentuated by the fragmentation of habitats and the heavy changes suffered by the estuarine and coastal environments, such as the increase in intensive farming practices, the diversion of waterways, tourism pressure related to seasonal variability of domestic effluents and to nautical activities, the use of wetlands for rice cultivation, and aquaculture $[5,55]$. The tendency of $A$. iberus to prefer isolated areas is one of the main factors that threatens its survival in an environmental context in which human pressures have accentuated the fragmentation of the territory. The scarce gene flow, as in the case of A. fasciatus, can seriously compromise adaptative processes. In addition, habitat destruction (e.g., salt mines along the coast), water pollution and the introduction of exotic species, especially Gambusia holbrooki, are factors that need to be counteracted and to which conservation actions need to be directed. Laboratory and mesocosm experiments have identified the possible negative effects that $G$. holbrooki can have on native populations. The coupling of G. holbrooki's aggressive behaviour toward A. iberus's adults and the predation on its juveniles increases stress, reduces feeding rates and decreases reproductive activities [60]; although, in the wild, it tends to live more on the seabed and in saltier waters, and, hence, has fewer direct interactions with G. holbrooki.

In addition, continental populations, which live in small streams, are at risk of decline due to poor management of aquifers, which may experience periods of drought [57]. The combination of habitat degradation with the presence of invasive species puts this species at risk according to IUCN assessments and in an unfavourable/inadequate state of conservation [61]. The species is reported at 39 Natura 2000 sites but only 29 are coastal lagoons (Table 3) and they are all distributed along Mediterranean coasts of Spain.

\subsection{Management}

Restoration efforts aimed at increasing the connectivity of habitats in the Ebro Delta, after about 2-3 years did not show significant increases in the populations of $A$. iberus, which indeed decreased, probably due to climatic events (very low temperatures in winter and heavy rainfall with a consequent sudden change in salinity [54]). It is believed that the success of habitat restoration actions or introductions of individuals for repopulation would take about 10 years to determine whether the population will survive [54,57]. However, the reintroduction of $A$. iberus, also, may not be sufficient to reinforce the wild populations because the gene diversity is globally poor [59]. Alcaraz and García-Berthou [41] observed that the periodically flooded glasswort habitats presented a higher density of mature $A$. iberus, with the availability of both aquatic and terrestrial preys and a greater foraging efficiency. Beyond the preservation of the few areas where $A$. iberus is still present, the functional role of flooded habitats, such as the glasswort, may have significant implications to improve its conservation status [41]. A. iberus is demographically more fragile, and its distribution is more difficult to be managed than that of $A$. fasciatus. Despite this, more intervention projects (both national and international) have been dedicated to the management and the recovery of the Spanish endemism. Since 1996, three Spanish projects were co-funded by European LIFE programme aiming at 
the conservation of the species by means of habitat restoration (LIFE96 NAT/E/003118 -introduced 20,000 specimen in Catalonia deltas [62]; LIFE99 NAT/E/006386-restored wetlands in Catalan Baix Ter coastal lagoon [63]; LIFE09 NAT/ES/000520-recovered Ebro Delta's Alfacada and Tancada lagoon hydrologic functioning [64]). Therefore, as for $A$. fasciatus, the habitat restoration is the first objective to be addressed, even though particular attention has to be paid to the introduction of alien species. At present, G. holbrooki does not appear to be a threat [60], but the introduction of further competitive species can be lethal. In fact, another potential competitor could be Fundulus heteroclitus [65,66], which can live also in brackish and estuarine waters, even though, at present, the effects of the interaction between the two species is not described.

\section{Knipowitschia panizzae (Verga, 1841)—Order Gobiiformes}

\subsection{Biology and Distribution}

K. pannizae is an euryhaline species, endemic in the Adriatic and the Ionian Sea, where it lives in shallow, well-vegetated environments such as streams, lakes, estuaries, lagoons and terminal stretches of rivers [67]. The body is grey-yellowish with darker and reticulated mottles; the females have a body and fins that are brighter than those of males and during spawning the females' bellies are yellow [68]. It is a small predator (a few centimetres in length), of no commercial interest [69], opportunist and generalist [70], that feeds, above all, on meio-fauna and juvenile macrofauna [71-74]. Reproduction takes place in brackish waters where the life cycle is completed in about 1 year, as adults disappear after spawning during their second summer of life $[69,75]$. Females are generally more abundant than males [75]; moreover, the female density increases during the reproductive period, but this observation can be biased by a lower susceptibility to catching of males that remain close under the nest [69].

The reproductive strategy is r-type (abbreviate iteroparity, sensu Miller [76]), suitable for unstable environments, which leads to a rapid increase of individuals, a long breeding season with multiple spawning, and females who release at each spawn about 100-150 eggs within the nests of different males. Males, that are territorial, carry out parental care and preferably use bivalve shells as shelter and a breeding site. Both the male and the female produce sounds, while the female approaches the nest [39]. The male emits sounds while remaining in the nest and the female produces them only when the ventral part is almost in contact with the male's head. The sounds cease when the female moves away, and are not produced during courtship outside the nest, nor during the spawning. Although it is not entirely clear the role of these "pre-deposition" sounds, they are supposed to influence the choice of the male by the female [77]. The species has sexual dimorphism that manifests, above all, in the nuptial coloration of the female with a conspicuous yellow/orange pigmentation in the ventral part. This coloration depends on the pigmentation of the dermis and is closely linked to the spawning: in fact, it disappears afterwards. The presence of nuptial coloration is a signal indicating the approaching spawning and its size, which varies from individual to individual, is a reliable indicator of the quantity of eggs that will be released [78]. Since the reproductive success of the male depends on the fertility of the female, it is believed that the conspicuousness of the nuptial coloration is the ornamental character on which the male bases its choice [79]. In fact, there is no evidence of competition between females and there is no correlation between body length and ventral coloration conspicuousness [78]. It is a carotenoid-based pigmentation, which can be considered indicative of the good health of the organism. Therefore, it is believed that the male chooses females with a bigger yellow ventral patch since they are in better condition and therefore are more fertile, preferring them also to larger females but with a less extensive coloration [79]. After breeding, adults die and only juveniles survive [70,75].

The high plasticity in the diet and the reproductive strategy make this species able to survive in very unstable environments. Very abundant populations of K. panizzae have been observed in hypertrophic basins, such as Comacchio lagoons, where dystrophic crises are frequent. This population is probably favoured by the great availability of preys before dystrophic crises, then, during the 
unfavourable conditions, individuals move away to areas with greater circulation and oxygenation [67]. It has also been observed, with laboratory experiments, that, as a survival strategy, in particular environmental conditions, intraspecific cannibalism can occur on juveniles or adults. Such events seem not to be determined by just food shortages but by a combination of factors: low availability of food in the reproductive period or poor quality of prey, as can happen during an anoxic crisis [74].

\subsection{Conservation Status}

K. panizzae is not a species considered to be at risk (for IUCN it is least concern and the conservation status is favourable) and can survive, as in the example of Comacchio, even in the case of high eutrophication, but the destruction of original habitats, mainly from a morphological point of view, can result in local population decline. In the Venice lagoon, K. panizzae was found to considerably prefer canals inside the salt marshes, compared to the open lagoon complex [80]. Its density, in fact, can vary significantly on both spatial and temporal scales: the annual mean in a saltmarsh creek was found to be $1374 \pm 3167 \mathrm{ind} / \mathrm{ha}$, while in a saltmarsh close to man-regulated canals it was $58 \pm 80 \mathrm{ind} / \mathrm{ha}$; during summer, in the saltmarsh creek, up to 14,000 ind/ha can be collected [69], while in autumn density can be $780 \pm 1402 \mathrm{ind} / \mathrm{ha}$ [80]. The preference for more sheltered areas and possibly with macroalgal cover may depend, also, on the potential greater availability of bivalve molluscs of the genus Cerastoderma, whose shells are chosen as nest by males [39]. As a result, erosion and alteration of the natural habitat, with the decline or disappearance of the structures of salt marshes can compromise the population vitality [69].

K. panizzae was reported in 34 Natura 2000 sites, 25 of whose are coastal lagoons (Table 3) distributed along the Adriatic coast both on Italian and Balkan side [81,82]. However, recent phylogenetic studies, based on mitochondrial DNA analysis, have shown that K. mrakovcici, K. radovici and K. panizzae are not distinct species and are all K. panizzae [12], so the distribution range of the species should be reconsidered. The Adriatic and Ionian seas are the centre of diversity for sand gobies, with a total of 17 species belonging to five genera, including Knipowitschia and Ninnigobius [12]. The wide distribution of K. panizzae and the high ability to survive in extreme conditions allows us to suppose a good intraspecific genetic diversity, favoured also by the panmictic behaviour and by the presence of a free postlarval stage, favouring specimen dispersion with tide currents. However, there is a lack of specific studies comparing the genetic diversity among populations from different regions.

\subsection{Management}

Sand gobies are often dominant and they can be used as an indicator of habitat productivity. In Venice lagoon saltmarshes, in particular, their productivity was found to be higher than in other Mediterranean wetlands, reaching up to a total annual production $>600 \mathrm{~g} \mathrm{ha}^{-1}$ year $^{-1}$ [70]. The main threat compromising this significant contribution to secondary production in coastal lagoons is represented by the destruction of saltmarshes. K. panizzae itself is not at risk of extinction, given its high adaptability. In Italy, in fact, accidental introductions are reported along the Tyrrhenian coast, in Trasimeno and Bolsena Lakes and in Sicily, with good survival $[39,70,83]$. The concern could be on the survival of local populations that have to be preserved, protecting or restoring saltmarsh systems. Moreover, the reproductive rate of K. panizzae could be reduced by the absence of the preferred bivalve shells for nest. Beyond the interventions to preserve coastal lagoon shallow habitat, river systems can also have a significant role in population survival, as demonstrated by the fact that the populations so far attributed to K. mrakovcici and K. radovici are K. panizzae and usually live in freshwater environments in the Croatian Krka and Neretve basins [12]. Since 2010, K. panizzae has been among the target species of three Italian projects co-funded by European LIFE programme (LIFE10 NAT/IT/000256-improved hydraulic circulation and as a consequence water quality in Italian coastal salt meadows [84]; LIFE12 NAT/IT/000331—contributed to the achievement of good ecological status by transplanting seagrasses in some areas of the Venice lagoon [85]; LIFE13 NAT/IT/000115—improved hydraulic conditions in Po delta's Sacca di Goro [86]). 
On the other hand, particular attention has to be paid to the accidental introduction of K. panizzae in other basins, because it can become invasive and compromise the ecological equilibrium in fragile ecosystems [70], entering in competition with local species with a similar ecological niche.

\section{Ninnigobius canestrinii (Ninni, 1883)—Order Gobiiformes}

\subsection{Biology and Distribution}

Pomatoschistus canestrinii has recently been attributed to the genus Ninnigobius, which includes few species, but is phylogenetically well-distinguished by both Pomatoschistus and Knipowitzschia [12]. $N$. canestrinii is a small goby (about $6.5 \mathrm{~cm}$ ), epibenthic, of no commercial interest and endemic of the Adriatic basin $[39,67,69]$. The lifespan is at most 16 months, and the spawners disappear after spawning [75]. The body is grey to bright brown, marked with very clear black points at least on the cheeks and the opercula; males are significantly larger than females, whose coloration is, on the whole, paler than that of the males, especially during the breeding period [68]. It lives preferentially in unvegetated sandy or muddy environments at the mouths of rivers or in the shallow lagoon areas $[39,80]$, feeding on small meiobenthic invertebrates $[75,87]$. Its preferred habitat, characterized by low salinity, high turbidity, shallow waters and the presence of bivalve beds, is very similar to K. panizzae's one $[80,88]$. However, N. canestrinii is known to prefer lower salinity and saltmarsh-dominated areas in the inner part of the Venice lagoon [89]. This should not depend on competition between the two species, because the choice of nest, reproduction times and predation tactics $[39,80]$ are different, although there are similarities in the behaviour, including the production of sounds during the reproductive period $[77,90]$. N. canestrinii is less selective in the choice of the nest, which is created using shells, stones, bowls and any submerged object [39]. The male has a territorial behaviour for the defence of the nest and carries out parental care until the hatching of the eggs. Although the mechanism of sound production is not clear, it has been observed that, in the phase immediately before the spawning, the male "communicates" with the female, which in turn manifests a very active behaviour [90].

The species of the Gobionellidae family are often dominant in the communities of temperate and tropical transition environments [91] and, above all, the smaller ones play an important role in the trophic network as they favour the turnover of resources present in mobile sediments [69]. Well-structured populations are present in the lagoon of Venice $[80,88]$ and in the basins of the Comacchio lagoons [67]. However, since this species does not tolerate salinity over 30, it is often also observed in oligohaline and freshwater environments [87], in some of which it was introduced accidentally, i.e., Trasimeno Lake in Italy [92] and reservoir of the Ričica River in Croatia [82,93]. Records were also made in Bosnia-Herzegovina, in the freshwaters of the coastal lake Svitava in the Neretve basin [94]. As the environmental characteristics of the Neretve Delta are potentially ideal as a habitat for N. canestrinii, Tutman et al. [94] hypothesize that it has always been present in that areas, but that in the past no special attention has been paid to investigate its presence.

\subsection{Conservation Status}

Compared to K. pannizae, N. canestrinii distribution is geographically more restricted (Table 3), abundant only in the Northern part of the Adriatic Sea, but it can reach a similar or higher density. In the Venice lagoon, in fact, its annual mean in the saltmarsh creek was found to be $1137 \pm 2780 \mathrm{ind} / \mathrm{ha}$ (K. pannizae was $1374 \pm 3167 \mathrm{ind} / \mathrm{ha}$ ), while it resulted more abundant than K. panizzae in other saltmarsh zones, less sheltered but with lower salinity: N. canestrinii $239 \pm 247$ ind/ha compared to K. pannizae $58 \pm 86$ ind/ha [69]. Despite the fact that N. canestrinii shows a preference for saltmarsh creeks, it can be found also in more open areas, with biomass one order of magnitude higher than that of K. pannizae ( $N$. canestrinii $115 \pm 159 \mathrm{~g} / \mathrm{ha}$ compared to K. pannizae $11 \pm 16 \mathrm{~g} / \mathrm{ha}$ ) [69]. Considering the seasonal distribution, $N$. canestrinii was found to have similar density in both saltmarsh creeks $\left(5.60 \pm 15.61 \mathrm{ind} / 100 \mathrm{~m}^{2}\right.$ in summer and $3.26 \pm 9.81 \mathrm{ind} / 100 \mathrm{~m}^{2}$ in winter) and mudflats $\left(3.32 \pm 5.94 \mathrm{ind} / 100 \mathrm{~m}^{2}\right.$ in summer and $4.87 \pm 11.58 \mathrm{ind} / 100 \mathrm{~m}^{2}$ in winter) [80]. 
As an oligohaline species, N. canestrinii can be common also in freshwater habitats, where other factors could threat its local population survival. For Trasimeno Lake, for example, it has been hypothesized that the Eurasian copepod Lernaea cyprinacea could infest the host, generally belonging to the Gobionellidae family, causing its death [95]. At present, there is no evidence of parasitism on $N$. canestrinii and it is established that in brackish waters this risk is remote because L. cyprinacea does not tolerate even low salinity [95].

According to IUCN assessments, the threat level for $N$. canestrinii is least concern and the status is favourable [96]. Its presence is reported in 26 Natura 2000 sites, 20 of which are priority habitats $1150^{*}$ (Table 3). The restricted range can determine limited gene flow, reducing the intraspecific genetic biodiversity, but no data are available in the literature describing the difference among populations. Although not considered to be an endangered species, its distribution and density should be carefully monitored, because it represents a good indicator of the conservation status of coastal lagoon habitats in its structural and morphological complexity (salts, small canals, shallow bottoms, etc.) and is important for nekton community biodiversity.

\subsection{Management}

The preservation of the habitats suitable for $N$. canestrinii survival is the main objective to be achieved by creating protection plans that regulate the human activities [87]. However, from 1992 to 2018, only four Italian projects co-funded by European LIFE programme, dedicated to restoration of coastal lagoon ecosystems, indicated $N$. canestrinii among target species that would benefit from the interventions ([84-86] and LIFE16 NAT/IT/000663-restoration of salinity gradient in an area of the Venice lagoon from salinity $<5$ towards $<15$ up to $<25$ [97]). One of them pays particular attention to the salinity values, introducing freshwaters and restoring the lagoon original gradient that would favour N. canestrinii increase $[89,97]$. Despite that it shares the same sub-habitat as K. panizzae, no competition seems to exist, whereas in the Po Delta, difficulties to access the structures to build the nest have been observed for the coexistence between Pomatoschistus marmoratus and Salaria pavo [18]. Therefore, particular attention has to be paid to keep not only the morphological structures of saltmarshes with their tidal creeks and pools, but also the bottom undisturbed to favour the presence of submerged objects, such as shells. On the fishing management plans, the activities impacting the bottoms have to be carefully assessed to avoid the sediment resuspension and the nest destruction. As an example, in the late 1990s, in the Venice lagoon, the clam harvesting activity with hydraulic and mechanical dredging systems that dug $10-30 \mathrm{~cm}$ deep furrows dramatically affected the biological equilibrium and the benthic communities $[98,99]$.

Moreover, the introduction of allochthons Gobionellidae could be a serious threat due to the competition for resources.

\section{Valencia spp.-Order Cyprinodontiformes}

In Annex II of the Habitat Directive, other two Cyprinodontiformes species are listed belonging to the family Valenciidae: the Spanish endemism Valencia hispanica and the Greek Valencia letourneuxi. Both $V$. hispanica and V. letourneuxi are priority species (indicated with an asterisk in Annex II, under Article 1 letter $\mathrm{h}$ ), whose preservation required special responsibility. They are freshwater species, but, living in coastal lakes or pounds and sometimes tolerating low salinity, can be a significant indicator of coastal lagoon status.

\subsection{Valencia hispanica (Valenciennes, 1846)}

\subsubsection{Biology and Distribution}

The distribution of $V$. hispanica is limited to the coast of eastern Spain, where it lives in small freshwater systems (pools and marshes) and occasionally in brackish areas, such as lagoons or estuaries. Adult males, on average smaller $(<6.7 \mathrm{~cm})$ than females $(<7.1 \mathrm{~cm})$, have a blue-grey 
coloration with narrow dark cross bars and yellow/orange edge on pectoral and caudal fins. They are slow-growing individuals who can live beyond 4 years for females and over 3 for males; sexual maturity is reached late, but multiple spawning can be observed in the period between April and June [100]. Although behavioural differences among individuals of the same population can occur, the general tendency of the species is to feed on 3 types of prey (Gammaridae, Sphaeromatidae and Chironomidae larvae) and preferably on living organisms, which live in the muddy/sandy vegetated seabed or on the surface of the water. The high specialization in the diet, even if prey of other groups can be available, seems to be one of the main constraints for the survival of the species [56]. In addition, other threats are added, such as habitat loss or fragmentation, the introduction of exotic species such as Gambusia holbrooki, and worsening water quality. V. hispanica and G. holbrooki can interact frequently because they tend to move vertically in the water column. Numerous G. holbrooki aggression phenomena have been observed, with negative consequences for $V$. hispanica courtship activities and feeding rates [60].

\subsubsection{Conservation Status}

According to Oliva-Paterna et al. [87], the number of natural populations of $V$. hispanica is 10, five of which are considered to be in a good state of conservation. Caiola et al. [55] reports four populations in the estuaries, but according to Natura 2000 reports, the species is present in 16 sites, 13 of which are coastal lagoons (Table 3). Despite the discrepancy in the information, the number of natural populations is still dramatically low, and, in fact, the threat level is critically endangered. The general conservation status is unfavourable/bad [101].

\subsubsection{Management}

In addition to international regulations, it is also protected at the national level, as it is one of the most endangered species of fish fauna at European level. Moreover, since 1993, in the framework of European action programmes, more than 100,000 individuals have been reintroduced in the Valencian region (2500 individuals in the framework of the LIFE04 NAT/ES/000048-aiming at recovering two permanently flooded freshwater pools [102]) and 35,000 specimens were re-introduced in the Ebro delta (Catalonian region; LIFE96 NAT/E/003118 [62]), but at present, the effects of such activities do not appear relevant to preserve the local populations [100].

\subsection{Valencia letourneuxi (Sauvage, 1880)}

\subsubsection{Biology and Distribution}

$V$. letourneuxi is distributed along the west Greek coast. It is a short-lived species that lives in temperate freshwater basins along the coast and can tolerate a salinity up to 4 [103]. Its original range was a basin in Corfu island (Greece), although it has not been recorded there in recent decades; however, it is widespread from the southern coast of Albania to the Peloponnese. Although it has also disappeared from other aquatic systems due to several causes (water pollution for dairy activities, drying of springs, etc.), the original wide distribution along the coast has prevented the complete extinction of the species [104]. The number of populations is in constant decline and the local density very low (i.e., in the Greek Kalamas river system, V. letourneuxi was found only in one site with a relative density $<1 \%$, [103]). Its typical habitats are spring streams with deep water and low current speed, with bottoms covered with an adequate bed of vegetation that provides food, protection and substrate for spawning [103]. 


\subsubsection{Conservation Status}

Beyond pollution and water extraction, the strong competition with Gambusia holbrooki is a significant threat $[103,104]$. Under IUCN assessments, the species is critically endangered and the conservation status is unfavourable/inadequate [105]. In coastal lagoon environments, it has been reported in two Greek sites (Table 3): the Delta Acheloou, Limnothalassa Mesolongiou—Aitolikou, Ekvoles Evinou, Nisoi Echinades, Nisos Petalas and the Limnes Voulkaria Kai Saltini.

\subsubsection{Management}

From 1993 to 2018, no European LIFE project was funded having as target species V. letourneuxi. Suggested interventions to improve the conservation status are nutrient load control, regulation of water extraction activities and, possibly, the reintroduction of adults for reproduction.

\section{Discussion}

The natural complexity of coastal lagoons is the result of a wide range of situations, mainly driven by the degree of confinement, the ionic composition and the salinity variations depending on evaporation vs. inputs from rivers and seas. This determines the absence of a clear or unidirectional salinity gradient and leads to a three-dimensional heterogeneity, influencing the species composition and favouring the dominance of a few ecological guilds, such as, for fish fauna, the marine migrants [106]. However, several studies demonstrated the significant role of lagoon geomorphological features to explain fish assemblages in terms of both productivity, taxonomic and functional diversity ([107-109] and references therein). According to the Ramsar convention, wetlands (including coastal lagoons) are "areas of marsh, fen, peatland or water, whether natural or artificial, permanent or temporary, with water that is static or flowing, fresh, brackish or salt, including areas of marine water the depth of which at low tide does not exceed six metres" [110]. Tidal wetlands have a significant role in selectively trapping fine sediments, influencing the water residence time and sequestering nutrients and pollutants [111]. In the present paper, the main focus is on the importance of fish fauna in two structures that characterize coastal lagoons of middle and high latitudes: salt marshes and mudflats. Marshes can be found in all aquatic environments where the erosive forces, produced by waves and currents, are weak and a sheltered and sedimentary environment prevails. Along coasts, the amplitude of the tidal regime determines the salt marsh structure, extension and the habitats within a salt marsh, that can be characterized by creeks and pools, which provide diverse habitats for aquatic vegetation and animals [112]. Nearby salt marshes, mud flats are the structures periodically inundated by the tide and their characteristics vary depending on the tide excursion. According to Wolanski and Elliott [111], "Mudflats located below neap high tide are wetted daily by the tides and the top layer of the mud is commonly soft and unconsolidated. Mudflats between the neap and spring tide high water marks are wetted on alternate weeks, whereas those in supratidal areas are tidally inundated only at the highest astronomical tides."

Multifactorial approaches are recommended to describe the ecological status of coastal lagoons [106], due to the high heterogeneity described above and also considering that the larger the lagoon, the greater the habitat diversity [108]. Traditional metrics or the indices developed in the framework of National and International laws mainly focus on the water quality or on rapid environmental changes. Often, the information on the rate and impact of erosive processes that affect lagoon morphology on a long-term scale is missed. Therefore, the use of indicator species can add additional support to decision-makers, targeting specific management actions to habitat restoration [15], focusing on morphological alterations, salinity changes, and the presence of invasive alien species. Ecological indicator species are sensitive to particular environment attributes [113], so their presence and abundance can provide information on it [15]. Despite that marine migrants, mainly juveniles, received much more attention in coastal lagoon research, due to their fishery importance, the few fish species of lagoon residents are more abundant [91,114-116] and can be more suitable indicators 
due to their low dispersal abilities and strong relationships with lagoon morphological structures during their entire life cycle. Some evidence on the relationship between morphological degradation and the status of nekton community highlighted that the effects of pressures acting on the lagoon morphology are stronger for resident species than for marine migrants [117]. As an example, the populations of Atherina boyeri (Risso, 1810), a small estuarine resident of commercial interest, resulted to be significantly affected by pressures deriving from the morphological (hydrological) alteration in Marano-Grado lagoon system (Northern Adriatic Sea) [118].

\subsection{Cyprinodontiformes (Aphaniidae and Valenciidae)}

Among the lagoon residents included in Annex II of the Habitat Directive here presented, A. fasciatus is recognized to be a typical component of the fish community of saltmarsh systems [114,119], which generally represent important transition areas in buffering flood phenomena [31] or in supporting the morphological complexity that counteracts the increasing inputs of seawaters. The in-depth study of A. fasciatus bio-ecology could provide the necessary tools to monitor and manage the erosion processes that affect its habitat.

The present overview highlights the occurrence of $A$. fasciatus in brackish to hyperhaline systems characterized by shelter habitats: such as small-sized intertidal creeks (200-250 m long, 2-4 m width), with a maximum depth of $0.7 \mathrm{~m}$ [49]. A. fasciatus seems to be able to tolerate eutrophic waters, but it needs small tidal creeks or sheltered canals to maintain successful reproductive and survival rates, indicating a significant relationship with the structure of saltmarshes. Moreover, sites with around 15\% of organic matter were found to better support the local population than the zones with a percentage around $7 \%$ [28]. Locally, healthy populations were found to reach an annual mean higher than $100 \mathrm{ind} / 100 \mathrm{~m}^{2}$ [28], while in the areas where a decreasing trend was observed, the catching accounts for few specimens $[34,44]$. The presence of aquatic vegetation coverage is another fundamental factor.

Beyond salt marsh degradation, and due to an increasing erosive process, habitat fragmentation also tends to accentuate population isolation and weaken their genetic heritage and, in the long term, adaptive capacity. The effects of habitat fragmentation and the consequent increase of isolation would be evident in the future, when the intraspecific genetic diversity will be drastically reduced.

Furthermore, A. fasciatus was demonstrated to be strongly related to artificial habitats, such as salt works and small man-made creeks [28,49], that are important components of the lagoon landscape, as the historical product of the interaction between traditional human activities and the lagoon coastal habitats. This species could, therefore, be considered indicator species for these peculiar components of the lagoon landscape, contributing to support its conservation and management.

The use of $A$. fasciatus as a sentinel of anthropogenic impacts in Mediterranean coastal lagoons is well-documented [51,120,121]. In fact, Kessabi et al. [51] believe that it may be a good indicator for detecting metal and organic pollutants by using mRNA biomarkers. Heavy metal pollution effects were, in fact, documented in both reproductive function [50] and spinal deformities [51]. Mossesso et al. [120] proposed A. fasciatus like a promising "sentinel organism" to detect the genotoxic impact of complex mixtures in coastal lagoon ecosystems.

As endemic species, $A$. iberus, that is, the most endangered species among lagoon residents, and $V$. hispanica and $V$. letourneuxi, which are priority species, can provide information on local habitats of high ecological value. In particular, $A$. iberus can be used as an indicator of the functional complexity of the lagoon ecosystem, with a habitat affinity similar to that of A. fasciatus, while the Valencia spp. are sensitive to hydrological variations and salinity increase. A. iberus was found to be more abundant far from the sea and to prefer vegetated areas [54]. V. letourneuxi was found to tolerate a salinity up to 4 in the wild [103]. Therefore, the increase of seawater intrusion due to infrastructural intervention or aquifer management could have further compromised its presence. 


\subsection{Gobiiformes, Gobionellidae}

K. panizzae and N. canestrinii distribution is more limited than that of A. fasciatus; however, where present, they show important density, demonstrating an exclusive relationship with lagoon morphology. K. panizzae partially provides similar information as A. fasciatus does for saltmarsh systems, but it is also sensitive to alteration of mudflats (sensu Wolanski and Elliott [111]), where males usually prepare the nests. Therefore, the creation of infrastructures (such as navigable canals and water pipe digging) or their maintenance and, in general, the use of dredging systems represents a serious threat for the local population, ending in the destruction of breeding sites. Males of both species need hard structures and cavities to build their nest, such as shells or other artificial structures. This means that the substrate of their breeding habitats should be structurally complex.

Depending on the habitat structure, the literature demonstrates that the population density of K. panizzae can vary by even up to two orders of magnitude. Approximately, it can be supposed that a population with an annual density below $100 \mathrm{ind} / 100 \mathrm{~m}^{2}$ should be monitored with particular care.

Despite being able to tolerate high eutrophicated systems [67] and suffering from the alteration and fragmentation of native habitats, due to the loss of typically lagoon morphologies as in the case of A. fasciatus and K. panizzae, N. canestrinii is particularly sensitive to salinity increase, its optimal salinity values ranging from 2 to 20 and never exceeding 30 [87]. Human-regulation of water exchanges is frequent in Mediterranean costal lagoons to meet the need for numerous anthropogenic activities, such as navigation and fishing and aquaculture, and to maintain the functioning of the ecosystem [122]. Modifying communication with the sea and dredging canals may lead to significant changes in retention time [123] and salinity values [122]. Moreover, the ongoing climate changes and the future sea-level rise can accentuate these processes, increase eutrophication and accelerate the erosion rate of wetlands $[5,124]$. Although the species seems to not be affected by high eutrophication levels, the salinity rise and the saltmarsh degradation remain a serious threat. In light of these considerations, the decrease of $N$. canestrinii populations could be a marker of environmental processes leading to higher salinity and a higher sea level, indicating a direction of change in coastal lagoons towards marine environments.

\subsection{Conservation Management Issues}

Consulting the European Union database and the literature:

(1) At the European level, few management actions have been undertaken since the issue of the HD. Despite the attention of European Union towards habitat conservation status, in the period from 1992 to 2018, 1691 projects were co-financed through the LIFE Financial Programme (Sub-Programme Environment-Nature and biodiversity). These projects were specifically dedicated to promoting conservation efforts of Natura 2000 Network sites and/or of Community interest species listed in Annex II of the Habitat Directive. Among the 1691 projects, 682 were carried out by the Member States which have coasts bordering the Mediterranean Sea and 60 to the priority habitat $1150^{*}$. Excluding the Atlantic lagoons of France and Spain, there were 52 projects left for Mediterranean lagoons and only 10 explicitly stated the objective of improving environmental conditions in relation to fish species of Community interest and especially those of the Aphanius species. From this information, it is not possible to understand if few proposals were submitted by Member States or if they were not targeting the LIFE Financial Programme aims, and, thus, were not financed, but the number sounds very low. Therefore, more attention towards the here-discussed species has to be paid in light of their role as potential indicators of ecosystem conservation status.

(2) At the national level, some interventions were dedicated to the Spanish endemisms A. iberus and $V$. hispanica, but with poor success. 
(3) In the European Union, the regulation 1143/2014 [125] entered into force on 1 January 2015, to set common rules that allow the Member States to coordinate actions with the aims of preventing, early detecting, rapidly eradicating and managing invasive species. The core of Regulation (EU) 1143/2014 is the list of Invasive Alien Species (IAS) of Union concern, which includes four fish species (three freshwaters and one marine species), subject to restrictions and measures for the early detection and rapid eradication. None of these species are of concern for coastal lagoon habitats, but, as an example, Gambusia holbrookii, that was demonstrated to be aggressive and competitive towards Aphanius spp. and Valencia spp. in oligohaline waters, is not in the list. G. holbrooki already drove the A. fasciatus population to extinction in some Italian inland waters [33] and $V$. hispanica is seriously at risk. Being among the 100 most invasive species at the international level [126] and demonstrating its aggressiveness, Gambusia should be included in the European list of IAS. At the moment, efficient solutions to the eradications of G. holbrooki are poorly documented, but efforts should be addressed to avoid further introduction.

(4) In the European basin of the Mediterranean Sea, some areas of particular importance for the conservation of species are: western Greece, the Acheloos Delta, along the Balkan coast, the Neretve Delta, along the northwest coast of the Adriatic Sea, the system of coastal lagoons from Grado-Marano to the Po Delta, along the coast of Mediterranean Spain, the Ebro Delta [127].

(5) The species discussed here are strongly related to local environmental features. Therefore, absolute density values indicating the limit between healthy condition and local extinction are difficult to be set at the Mediterranean basin level. The most important issue to be addressed is the local monitoring activity. The use of species included in the national and international regulations, as in the case here presented, could make their use as indicators more efficient, because:

a. data collection is compulsory, and in the case of Natura 2000, started in the mid-1990s and for all Member States, allowing the assessment of long-term trends on a large spatial scale;

b. data are comparable;

c. the access to funding can be facilitated.

\section{Conclusions}

The aim of the present paper was to summarise the information on the fish fauna of Community interest (sensu European Habitat Directive) in coastal lagoons and to highlight how they can provide indications on morphological conservation status of salt marshes and mudflats. The following was achieved:

(1) The complex of species Aphanius + Valencia could be used as indicator of habitat alterations in coastal lagoons, focusing, in particular, on salt marsh complexity, habitat connectivity within the lagoon or among adjacent lagoon systems and the presence of a system of artificial habitats, such as salt-works and man-made creeks. The presence and abundance of these species indicate, in fact, a mosaic of isolated and closed habitats, with respect to the open lagoons. The complex system of small creeks and pools has a significant role, not only for lagoon residents, but also for many other fish fauna species, also of commercial interest, such as marine migrants, of which juveniles exploit the trophic resource in saltmarsh areas. Together with A. fasciatus, K. panizzae, N. canestrinii, it is possible to find A. boyeri, Sparus aurata (L.) and some species of the genus Chelon and of the family Sygnathidae [49]. V. hispanica was found in the same sampling site as Anguilla anguilla (L.), Mugil cephalus (L.), Pomatoschistus microps (Krøyer) and A. boyeri [55]. The lagoon residents are more sensible to local habitat alterations than marine migrants [101], therefore, the species belonging to Aphanius + Valencia genera can be considered umbrella species, through which protection and broader conservation objectives could be achieved also for other species [113], even of economic interest. Their decrease, as a consequence of habitat degradation due to sea level rise, excavations of canals and infrastructure development, can be recorded earlier 
than that of other guilds. Mainly A. fasciatus responds to the definition of umbrella species, being highly detectable and correlating with species diversity [15].

(2) A decrease in the presence and abundance of the two small gobies, K. panizzae and N. canestrinii, could partially indicate the same alterations in terms of habitat complexity and connectivity as Aphanius + Valencia, but they also provide information on the structural changes of the lagoon substrate that they use for nesting. Moreover, N. canestrinii selects a salinity range between 2 and 20 and could be useful as an indicator of oligohaline habitats, that could be threatened by significant rise of sea influence on coastal lagoon hydrodynamism.

(3) Beyond the morphological alterations, Aphanius + Valencia species could be used, also, as ecological indicators in relation to the distribution, occurrence and abundance of the invasive Gambusia complex or of other alien species compromising the coastal lagoon biological community.

(4) Mainly A. fasciatus was demonstrated to be particularly sensible to heavy metal contamination.

Author Contributions: Conceptualization, C.F. and S.M.; writing-original draft preparation, C.F.; writing-review and editing, F.C., P.F., S.M. All authors have read and agree to the published version of the manuscript.

Funding: This research received no external funding.

Acknowledgments: The authors are thankful to the editors and the anonymous reviewers for their comments and suggestions.

Conflicts of Interest: The authors declare no conflict of interest.

\section{References}

1. European Commission. Interpretation Manual of European Union Habitats; EUR 28. E. C.; DG ENVIRONMENT: Bruxelles, Belgium, 2013; p. 144.

2. Cataudella, S.; Crosetti, D.; Massa, F. Mediterranean Coastal Lagoons: Sustainable Management and Interactions among Aquaculture, Capture Fisheries and the Environment; Studies and Reviews. General Fisheries Commission for the Mediterranean. No 95; FAO: Rome, Italy, 2015; p. 278.

3. Natura 2000 Network Viewer. Available online: https://natura2000.eea.europa.eu/ (accessed on 4 December 2019).

4. European Environment Agency. European Topic Centre on Biological Diversity—Report under the Article 17 of the Habitats Directive Period 2007-2012. Available online: https://nature-art17.eionet.europa.eu/article17/ reports2012/ (accessed on 14 May 2020).

5. Newton, A.; Icely, J.; Cristina, S.; Brito, A.; Cardoso, A.C.; Colijn, F.; Riva, S.D.; Gertz, F.; Hansen, J.W.; Holmer, M.; et al. An overview of ecological status, vulnerability and future perspectives of European large shallow, semi-enclosed coastal systems, lagoons and transitional waters. Estuar. Coast. Shelf Sci. 2014, 140, 95-122. [CrossRef]

6. Kara, H.M.; Quignard, J.-P. Fishes in Lagoons and Estuaries in the Mediterranean 1: Diversity, Bioecology and Exploitation; John Wiley \& Sons: Hoboken, NJ, USA, 2018; p. 265.

7. Elliott, M.; Whitfield, A.; Potter, I.C.; Blaber, S.J.M.; Cyrus, D.P.; Nordlie, F.G.; Harrison, T.D. The guild approach to categorizing estuarine fish assemblages: A global review. Fish Fish. 2007, 8, 241-268. [CrossRef]

8. Franco, A.; Elliott, M.; Franzoi, P.; Torricelli, P. Life strategies of fishes in European estuaries: The functional guild approach. Mar. Ecol. Prog. Ser. 2008, 354, 219-228. [CrossRef]

9. Potter, I.C.; Tweedley, J.R.; Elliott, M.; Whitfield, A. The ways in which fish use estuaries: A refinement and expansion of the guild approach. Fish Fish. 2013, 16, 230-239. [CrossRef]

10. World Register of Marine Species (WORMS). Available online: www.marinespecies.org (accessed on 4 December 2019).

11. Bianco, P.G.; Ketmaier, V. A revision of the Rutilus complex from Mediterranean Europe with description of a new genus, Sarmarutilus, and a new species, Rutilus stoumboudae (Teleostei: Cyprinidae). Zootaxa 2014, 3841, 379-402. [CrossRef] 
12. Thacker, C.E.; Gkenas, C.; Triantafyllidis, A.; Malavasi, S.; Leonardos, I. Phylogeny, systematics and biogeography of the European sand gobies (Gobiiformes: Gobionellidae). Zoöl. J. Linn. Soc. 2018, 185, 212-225. [CrossRef]

13. International Union for Conservation of Nature. 2006 IUCN Red List of Threatened Species. 2006. Available online: http://www.iucnredlist.org/ (accessed on 1 March 2008).

14. European Environmental Agency. European Nature Information System. Available online: https://eunis.eea. europa.eu/ (accessed on 4 December 2019).

15. Gilby, B.L.; Olds, A.D.; Connolly, R.M.; Yabsley, N.A.; Maxwell, P.S.; Tibbetts, I.; Schoeman, D.S.; Schlacher, T.A. Umbrellas can work under water: Using threatened species as indicator and management surrogates can improve coastal conservation. Estuar. Coast. Shelf Sci. 2017, 199, 132-140. [CrossRef]

16. Bortone, S.A.; Dunson, W.A.; Greenawalt, J.M. Fishes as Estuarine Indicators. In Estuar. Indicators; CRC Press: Boca Raton, FL, USA, 2005; pp. 381-389.

17. Nelson, J.S.; Grande, T.C.; Wilson, M.V.H. Fishes of the World; Wiley: Hoboken, NJ, USA, 2016; p. 707.

18. Kara, H.M.; Quignard, J.-P. Fishes in Lagoons and Estuaries in the Mediterranean 2; Wiley: Hoboken, NJ, USA, 2019 ; p. 39.

19. Leonardos, I.; Sinis, A. Reproductive strategy of Aphanius fasciatus Nardo, 1827 (Pisces: Cyprinodontidae) in the Mesolongi and Etolikon lagoons (W. Greece). Fish. Res. 1998, 35, 171-181. [CrossRef]

20. Ferrito, V.; Pappalardo, A.M.; Canapa, A.; Barucca, M.; Doadrio, I.; Olmo, E.; Tigano, C. Mitochondrial phylogeography of the killifish Aphanius fasciatus (Teleostei, Cyprinodontidae) reveals highly divergent Mediterranean populations. Mar. Boil. 2013, 160, 3193-3208. [CrossRef]

21. Leonardos, I.; Sinis, A. Population age and sex structure of Apahnius fasciatus Nardo, 1827 (Pisces: Cyprinodontidae) in the Mesologi and Etolikon lagoons (W. Greece). Fish. Res. 1999, 40, 227-235. [CrossRef]

22. Cavraro, F.; Georgalas, V.; Malavasi, S.; Franzoi, P.; Torricelli, P. Population Structure and Reproductive Ecology of the Mediterranean Killifish Aphanius fasciatus (Nardo, 1827) in the Venice Lagoon. In Proceedings of the 4th European Conference on Coastal Lagoon Research, Montpellier, France, 14-18 December 2009; p. 279.

23. Leonardos, I. The feeding ecology of Apahnius fasciatus (Valenciennes, 1821) in the lagoonal system of Mesolongi (Western Greece). Sci. Mar. 2008, 72, 393-401. [CrossRef]

24. Maltagliati, F. Genetic divergence in natural populations of the Mediterranean brackish-water killifish Aphanius fasciatus. Mar. Ecol. Prog. Ser. 1999, 179, 155-162. [CrossRef]

25. Angeletti, D.; Cimmaruta, R.; Nascetti, G. Genetic diversity of the killifish Aphanius fasciatus paralleling the environmental changes of Tarquinia salterns habitat. Genetica 2010, 138, 1011-1021. [CrossRef]

26. Cavraro, F.; Varin, C.; Malavasi, S. Lunar-induced reproductive patterns in transitional habitats: Insights from a Mediterranean killifish inhabiting northern Adriatic saltmarshes. Estuar. Coast. Shelf Sci. 2014, 139, 60-66. [CrossRef]

27. Cavraro, F.; Torricelli, P.; Malavasi, S. Quantitative Ethogram of Male Reproductive Behavior in the South European Toothcarp Aphanius fasciatus. Boil. Bull. 2013, 225, 71-78. [CrossRef]

28. Cavraro, F.; Daouti, I.; Leonardos, I.; Torricelli, P.; Malavasi, S. Linking habitat structure to life history strategy: Insights from a Mediterranean killifish. J. Sea Res. 2014, 85, 205-213. [CrossRef]

29. Ćaleta, M.; Buj, I.; Miočić-Stošić, J.; Marčić, Z.; Mustafić, P.; Zanella, D.; Mrakovčić, M.; Mihinjač, T. Population genetic structure and demographic history of Aphanius fasciatus (Cyprinodontidae: Cyprinodontiformes) from hypersaline habitats in the eastern Adriatic. Sci. Mar. 2015, 79, 399-408. [CrossRef]

30. Ferrito, V.; Mannino, M.C.; Pappalardo, A.M.; Tigano, C. Morphological variation among populations of Aphanius fasciatus Nardo, 1827 (Teleostei, Cyprinodontidae) from the Mediterranean. J. Fish Boil. 2007, 70, 1-20. [CrossRef]

31. Maltagliati, F. Genetic monitoring of brackish-water populations: The Mediterranean toothcarp Aphanius fasciatus (Cyprinodontidae) as a model. Mar. Ecol. Prog. Ser. 2002, 235, 257-262. [CrossRef]

32. Cimmaruta, R.; Scialanca, F.; Luccioli, F.; Nascetti, G. Genetic diversity and environmental stress in Italian populations of the cyprinodont fish Aphanius fasciatus. Oceanol. Acta 2003, 26, 101-110. [CrossRef]

33. Valdesalici, S.; Langeneck, J.; Barbieri, M.; Castelli, A.; Maltagliati, F. Distribution of natural populations of the killifish Aphanius fasciatus (Valenciennes, 1821) (Teleostei: Cyprinodontidae) in Italy: Past and current status, and future trends. Ital. J. Zoöl. 2015, 82, 1-12. [CrossRef] 
34. Deidun, A.; Diacono, I.; Tigano, C.; Schembri, P. Present distribution of the threatened killifish Aphanius fasciatus (Actinopterygii, Cyprinodonitdae) in the Maltese Islands. Cent. Mediterr. Naturalist. 2002, 3, 177-180.

35. Zammit Mangion, M.; Deidun, A.; Vassallo-Agius, R.; Magri, M. Management of threatened Aphanius fasciatus at Il-Maghluq, Malta. In Proceedings of the Tenth International Conference on the Mediterranean Coastal Environment, MEDCOAST 11, Rhodes, Greece, 25-29 October 2011.

36. Valdesalici, S.; Brahimi, A.; Freyhof, J. First record of Aphanius almiriensis from Italy and notes on the distribution of Aphanius fasciatus (Teleostei: Aphaniidae). J. Appl. Ichthyol. 2019, 35, 541-550. [CrossRef]

37. Mediterranean Toothcarp-Aphanius fasciatus (Valenciennes, 1821). Available online: https://eunis.eea.europa. eu/species/430 (accessed on 14 May 2020).

38. Bertoli, M.; Giulianini, P.G.; Chiti, J.; De Luca, M.; Pastorino, P.; Prearo, M.; Pizzul, E. Distribution and Biology of Aphanius fasciatus (Actinopterygii, Cyprinodontidae) in The Isonzo River Mouth (Friuli Venezia Giulia, Northeast Italy). Turk. J. Fish. Aquat. Sci. 2019, 20, 279-290. [CrossRef]

39. Gandolfi, G.; Zerunian, S.; Torricelli, P.; Marconato, A. I Pesci Delle Acque Interne Italiane; Istituto Poligrafico e Zecca dello Stato: Roma, Italy, 1991; p. 617.

40. Basset, A.; Barbone, E.; Elliott, M.; Li, B.-L.; Jorgensen, S.E.; Lucena-Moya, P.; Pardo, I.; Mouillot, D. A unifying approach to understanding transitional waters: Fundamental properties emerging from ecotone ecosystems. Estuar. Coast. Shelf Sci. 2013, 132, 5-16. [CrossRef]

41. Alcaraz, C.; García-Berthou, E. Life history variation of invasive mosquitofish (Gambusia holbrooki) along a salinity gradient. Boil. Conserv. 2007, 139, 83-92. [CrossRef]

42. Alcaraz, C.; Pou-Rovira, Q.; García-Berthou, E. Use of a flooded salt marsh habitat by an endangered cyprinodontid fish (Aphanius iberus). Hydrobiologia 2007, 600, 177-185. [CrossRef]

43. Koutrakis, E.T.; Kamidis, N.I.; Leonardos, I.D. Age, growth and mortality of a semi-isolated lagoon population of sand smelt, Atherina boyeri (Risso, 1810) (Pisces: Atherinidae) in an estuarine system of northern Greece. J. Appl. Ichthyol. 2004, 20, 382-388. [CrossRef]

44. Zogaris, S. Conservation Study of the Mediterranean Killifish Aphanius fasciatus in Akrotiri Marsh, (Akrotiri SBA, Cyprus)—Final Report. Darwin Project DPLUS034 “Akrotiri Marsh Restoration: A Flagship Wetland in the Cyprus SBAs BirdLife Cyprus"; Nicosia, Cyprus. Unpublished final report. 2017; 64.

45. Buj, I.; Zanella, D.; Marčić, Z.; Ćaleta, M.; Mustafić, P.; Mihinjač, T.; Mrakovčić, M. New Records of Aphanius fasciatus (Valenciennes, 1821) along the Eastern Coast of the Adriatic Sea in Croatia. Croat. J. Fish. 2015, 73, 124-127. [CrossRef]

46. Franco, A.; Pérez-Ruzafa, Á.; Drouineau, H.; Franzoi, P.; Koutrakis, E.; Lepage, M.; Verdiell-Cubedo, D.; Bouchoucha, M.; López-Capel, A.; Riccato, F.; et al. Assessment of fish assemblages in coastal lagoon habitats: Effect of sampling method. Estuar. Coast. Shelf Sci. 2012, 112, 115-125. [CrossRef]

47. Keith, P.; Persat, H.; Feunteun, É.; Allardi, J. Les Poissons D'eau Douce de France; Muséum National d'Histoire Naturelle: Paris, France, 2011; p. 552.

48. Alcaraz, C.; Bisazza, A.; García-Berthou, E. Salinity mediates the competitive interactions between invasive mosquitofish and an endangered fish. Oecologia 2007, 155, 205-213. [CrossRef]

49. Cavraro, F.; Zucchetta, M.; Malavasi, S.; Franzoi, P. Small creeks in a big lagoon: The importance of marginal habitats for fish populations. Ecol. Eng. 2017, 99, 228-237. [CrossRef]

50. Annabi, A.; Saïd, K.; Messaoudi, I. Heavy metal levels in gonad and liver tissues-Effects on the reproductive parameters of natural populations of Aphanius facsiatus. Environ. Sci. Pollut. Res. 2013, 20, 7309-7319. [CrossRef] [PubMed]

51. Kessabi, K.; Navarro, A.; Casado, M.; Said, K.; Messaoudi, I.; Piña, B. Evaluation of environmental impact on natural populations of the Mediterranean killifish Aphanius fasciatus by quantitative RNA biomarkers. Mar. Environ. Res. 2010, 70, 327-333. [CrossRef] [PubMed]

52. Nicol, S.; Sabbadin, R.; Peyrard, N.; Chadès, I. Finding the best management policy to eradicate invasive species from spatial ecological networks with simultaneous actions. J. Appl. Ecol. 2017, 54, 1989-1999. [CrossRef]

53. Henkanaththegedara, S.M.; Stockwell, C.A. Intraguild predation may facilitate coexistence of native and non-native fish. J. Appl. Ecol. 2014, 51, 1057-1065. [CrossRef] 
54. Prado, P.; Alcaraz, C.; Jornet, L.; Caiola, N.; Ibanez, C. Effects of enhanced hydrological connectivity on Mediterranean salt marsh fish assemblages with emphasis on the endangered Spanish toothcarp (Aphanius iberus). PeerJ 2017, 5, e3009. [CrossRef]

55. Caiola, N.; Vargas, M.J.; De Sostoa, A. Feeding ecology of the endangered Valencia toothcarp, Valencia hispanica (Actinopterygii: Valenciidae). Hydrobiologia 2001, 448, 97-105. [CrossRef]

56. Alcaraz, C.; García-Berthou, E. Food of an endangered cyprinodont (Aphanius iberus): Ontogenetic diet shift and prey electivity. Environ. Boil. Fishes 2006, 78, 193-207. [CrossRef]

57. Oliva-Paterna, F.J.; Torralva, M.; Fernández-Delgado, C. Threatened Fishes of the World: Aphanius iberus (Cuvier \& Valenciennes, 1846) (Cyprinodontidae). Environ. Boil. Fishes 2006, 75, 307-309. [CrossRef]

58. Oliva-Paterna, F.J.; Ruiz-Navarro, A.; Torralva, M.; Fernández-Delgado, C. Biology of the endangered cyprinodontid Aphanius iberus in a saline wetland (SE Iberian Peninsula). Ital. J. Zoöl. 2009, 76, 316-329. [CrossRef]

59. Araguas, R.M.; Roldán, M.I.; García-Marín, J.-L.; Pla, C. Management of gene diversity in the endemic killifish Aphanius iberus: Revising Operational Conservation Units. Ecol. Freshw. Fish 2007, 16, 257-266. [CrossRef]

60. Rincón, P. Interaction between the introduced eastern mosquitofish and two autochthonous Spanish toothcarps. J. Fish Boil. 2002, 61, 1560-1585. [CrossRef]

61. Spanish Cyprinodont-Aphanius iberus (Valenciennes, 1846). Available online: https://eunis.eea.europa.eu/ species/431\#protected (accessed on 14 May 2020).

62. LIFE96 NAT/E/003118. Available online: http://ec.europa.eu/environment/life/project/Projects/index.cfm? fuseaction=search.dspPage\&n_proj_id=117\&docType=pdf (accessed on 4 December 2019).

63. LIFE99 NAT/E/006386. Available online: http://ec.europa.eu/environment/life/project/Projects/index.cfm? fuseaction=search.dspPage\&n_proj_id=562\&docType=pdf (accessed on 4 December 2019).

64. LIFE09 NAT/ES/000520. Available online: http://ec.europa.eu/environment/life/project/Projects/index.cfm? fuseaction=search.dspPage\&n_proj_id=3845 (accessed on 4 December 2019).

65. Bernardi, G.; Fernández-Delgado, C.; Gomez-Chiarri, M.; Powers, D.A. Origin of a Spanish population of Fundulus heteroclitus inferred by cytochrome b sequence analysis. J. Fish Boil. 1995, 47, 737-740. [CrossRef]

66. Oltra, R.; Todoli, R. Reproduction of the endangered killifish Apanius iberus at different salinities. Environ. Biol. Fish 2000, 57, 113-115. [CrossRef]

67. Lanzoni, M.; Gavioli, A.; Aschonitis, V.; Merighi, M.; Fano, E.A.; Castaldelli, G. Length-weight relationships of three estuarine species in the Comacchio Lagoon, Po River delta, Italy. J. Appl. Ichthyol. 2016, 32, 1284-1285. [CrossRef]

68. Haedrich, R.L. Fishes of the North-Eastern Atlantic and the Mediterranean; Whitehead, P.J.P., Bauchot, M.-L., Hureau, J.-C., Nielsen, J., Tortonese, E., Eds.; Unesco: London, UK, 1986; pp. 1019-1085.

69. Franco, A.; Franzoi, P.; Malavasi, S.; Zucchetta, M.; Torricelli, P. Population and habitat status of two endemic sand gobies in lagoon marshes - Implications for conservation. Estuar. Coast. Shelf Sci. 2012, 114, 31-40. [CrossRef]

70. Spinelli, A.; De Matteo, S.; Costagliola, A.; Giacobbe, S.; Kovačić, M. First record from Sicily of the Adriatic dwarf goby, Knipowitschia panizzae (Osteichthyes, Gobiidae), a threatened species or a threat for conservation? Mar. Biodivers. 2016, 47, 237-242. [CrossRef]

71. Franzoi, P.; Ceccherelli, V.U.; Rossi, R. Differenze di abitudini alimentari tra novellame e specie ittiche residenti in una laguna del Delta del Po. Oebalia Suppl. 1992, 17, 181-186.

72. Ceccherelli, V.U.; Mistri, M.; Franzoi, P. Predation Impact on the Meiobenthic Harpacticoid Canuella perplexa in a Lagoon of the Po River Delta, Italy. Estuaries 1994, 17, 283. [CrossRef]

73. Franzoi, P.; Marchetti, C. Regime alimentare di due specie di piccoli ghiozzi (Pisces, Gobiidae) in un ambiente salmastro del Delta del Po. In Proceedings of the Atti del VI Convegno Nazionale dell'Associazione Italiana Ittiologi Acque Dolci, Varese Ligure, Italia, 6-8 June 1996; pp. 128-142.

74. Marzano, F.N.; Gandolfi, G. Active cannibalism among adults of Knipowitschia panizzae (Pisces Gobiidae) induced by starvation and reproduction. Ethol. Ecol. Evol. 2001, 13, 385-391. [CrossRef]

75. Maccagnani, R.; Carrieri, A.; Franzoi, P.; Rossi, R. Osservazioni sulla struttura di popolazione ed il ruolo trofico di tre specie di gobidi (Kinpowitschia panizzae, Pomatoschistus marmoratus, Pomatoschistus canestrinii) in un ambiente del Delta del Po. Nova Thalassia 1985, 7, 373-378. 
76. Miller, P.J. The tokology of gobioid fishes. In Fish Reproduction: Strategies and Tactics; Potts, G.W., Wooton, R.J., Eds.; Academic Press: London, UK, 1984; pp. 119-152.

77. Lugli, M.; Torricelli, P. Prespawning sound production in mediterranean sand-gobies. J. Fish Boil. 1999, 54, 691-694. [CrossRef]

78. Massironi, M.; Rasotto, M.B.; Mazzoldi, C. A reliable indicator of female fecundity: The case of the yellow belly in Knipowitschia panizzae (Teleostei: Gobiidae). Mar. Boil. 2005, 147, 71-76. [CrossRef]

79. Pizzolon, M.; Rasotto, M.B.; Mazzoldi, C. Male lagoon gobies, Knipowitschia panizzae, prefer more ornamented to larger females. Behav. Ecol. Sociobiol. 2007, 62, 521-528. [CrossRef]

80. Malavasi, S.; Franco, A.; Fiorin, R.; Franzoi, P.; Torricelli, P.; Mainardi, D. The shallow water gobiid assemblage of the Venice Lagoon: Abundance, seasonal variation and habitat partitioning. J. Fish Boil. 2005, 67, 146-165. [CrossRef]

81. Painzza's Goby-Knipowitschia panizzae (Verga, 1841). Available online: https://eunis.eea.europa.eu/species/ 518 (accessed on 14 May 2020).

82. Ćaleta, M.; Marčić, Z.; Buj, I.; Zanella, D.; Mustafić, P.; Duplić, A.; Horvatić, S. A Review of Extant Croatian Freshwater Fish and Lampreys. Croat. J. Fish. 2019, 77, 137-234. [CrossRef]

83. Zerunian, S. Pesci delle acque interne d'Italia. In Quad. Cons. Natura, Min. Ambiente; Ist. Naz. Fauna Selvatica: Roma, Italia, 2004; Volume 20, p. 257.

84. LIFE10 NAT/IT/000256. Available online: http://ec.europa.eu/environment/life/project/Projects/index.cfm? fuseaction=search.dspPage\&n_proj_id=4065 (accessed on 4 December 2019).

85. LIFE12 NAT/IT/000331. Available online: http://ec.europa.eu/environment/life/project/Projects/index.cfm? fuseaction=search.dspPage\&n_proj_id=4838 (accessed on 4 December 2019).

86. LIFE13 NAT/IT/000115. Available online: http://ec.europa.eu/environment/life/project/Projects/index.cfm? fuseaction=search.dspPage\&n_proj_id=5057 (accessed on 4 December 2019).

87. Franco, A.; Fiorin, R.; Franzoi, P.; Torricelli, P. Threatened fishes of the world: Pomatoschistus canestrinii Ninni, 1883 (Gobiidae). Environ. Boil. Fishes 2005, 72, 32. [CrossRef]

88. Malavasi, S.; Gkenas, C.; Leonardos, I.; Torricelli, P.; McLennan, D.A. The phylogeny of a reduced 'sand goby' group based on behavioural and life history characters. Zoöl. J. Linn. Soc. 2012, 165, 916-924. [CrossRef]

89. Scapin, L.; Zucchetta, M.; Bonometto, A.; Feola, A.; Brusà, R.B.; Sfriso, A.; Franzoi, P. Expected Shifts in Nekton Community Following Salinity Reduction: Insights into Restoration and Management of Transitional Water Habitats. Water 2019, 11, 1354. [CrossRef]

90. Malavasi, S.; Valerio, C.; Torricelli, P. Courtship sounds and associated behaviours in the Canestrini's goby Pomatoschistus canestrinii. J. Fish Boil. 2009, 75, 1883-1887. [CrossRef] [PubMed]

91. Malavasi, S.; Fiorin, R.; Franco, A.; Franzoi, P.; Granzotto, A.; Riccato, F.; Mainardi, D. Fish assemblages of Venice Lagoon shallow waters: An analysis based on species, families and functional guilds. J. Mar. Syst. 2004, 51, 19-31. [CrossRef]

92. Freyhof, J. First record of Pomatoschistus canestrinii (Ninni, 1883) in lake Trasimeno. Riverine Idrobiol. 1998, 37, 107-108.

93. Jelić, D.; Špelić, I.; Žutinić, P. Introduced species community over-dominates endemic ichthyofauna of High Lika Plateau (Central Croatia) over a 100 year period. Acta Zoöl. Acad. Sci. Hung. 2016, 62, 191-216. [CrossRef]

94. Tutman, P.; Sanda, R.; Glamuzina, B.; Dulčić, J. First confirmed record of Pomatoschistus canestrinii (Ninni, 1883) (Gobiidae) from Bosnia and Herzegovina. J. Appl. Ichthyol. 2013, 29, 937-939. [CrossRef]

95. Ahnelt, H.; Konecny, R.; Gabriel, A.; Bauer, A.; Pompei, L.; Lorenzoni, M.; Sattmann, H. First report of the parasitic copepod Lernaea cyprinacea (Copepoda: Lernaeidae) on gobioid fishes (Teleostei: Gobonellidae) in southern Europe. Knowl. Manag. Aquat. Ecosyst. 2018, 419, 34. [CrossRef]

96. Canestrini's Goby-Pomatoschistus canestrinii (Ninni, 1883). Available online: https://eunis.eea.europa.eu/ species/578 (accessed on 13 May 2020).

97. LIFE16 NAT/IT/000663. Available online: http://ec.europa.eu/environment/life/project/Projects/index.cfm? fuseaction=search.dspPage\&n_proj_id=6223 (accessed on 4 December 2019).

98. Raicevich, S.; Granzotto, A.; Pastres, R.; Giovanardi, O.; Pranovi, F.; Libralato, S. Mechanical clam dredging in Venice lagoon: Ecosystem effects evaluated with a trophic mass-balance model. Mar. Boil. 2003, 143, 393-403. [CrossRef] 
99. Sfriso, A.; Facca, C.; Marcomini, A. Sedimentation rates and erosion processes in the lagoon of Venice. Environ. Int. 2005, 31, 983-992. [CrossRef]

100. Oliva-Paterna, F.J.; Caiola, N.; Torralva, M. Threatened fishes of the world: Valencia hispanica (Valenciennes, 1846) (Valenciidae). Environ. Boil. Fishes 2009, 85, 275-276. [CrossRef]

101. Valencia Tooth-Carp_Valencia hispanica (Valenciennes, 1846). Available online: https://eunis.eea.europa.eu/ species/624 (accessed on 13 May 2020).

102. LIFE04 NAT/ES/000048. Available online: http://ec.europa.eu/environment/life/project/Projects/index.cfm? fuseaction=search.dspPage\&n_proj_id=2609 (accessed on 4 December 2019).

103. Perdikaris, C.; Paschos, I.; Gouva, E.; Giakoumi, S.; Pappas, E.; Kalogianni, E. Rapid population collapse of the critically endangered Valencia letourneuxi in Kalamas basin of Northwest Greece. AACL Bioflux 2010, 3, 69-76.

104. Economidis, P. Endangered freshwater fishes of Greece. Boil. Conserv. 1995, 72, 201-211. [CrossRef]

105. Valencia letourneuxi (Sauvage, 1880). Available online: https://eunis.eea.europa.eu/species/12498 (accessed on 13 May 2020).

106. Pérez-Ruzafa, Á.; Marcos, C.; Perez-Ruzafa, I.M.; Pérez-Marcos, M. Coastal lagoons: "transitional ecosystems" between transitional and coastal waters. J. Coast. Conserv. 2010, 15, 369-392. [CrossRef]

107. Pérez-Ruzafa, Á.; Mompeán, M.C.; Marcos, C. Hydrographic, geomorphologic and fish assemblage relationships in coastal lagoons. Hydrobiologia 2007, 577, 107-125. [CrossRef]

108. Franco, A.; Franzoi, P.; Torricelli, P. Structure and functioning of Mediterranean lagoon fish assemblages: A key for the identification of water body types. Estuar. Coast. Shelf Sci. 2008, 79, 549-558. [CrossRef]

109. Scapin, L.; Zucchetta, M.; Sfriso, A.; Franzoi, P. Local Habitat and Seascape Structure Influence Seagrass Fish Assemblages in the Venice Lagoon: The Importance of Conservation at Multiple Spatial Scales. Chesap. Sci. 2018, 41, 2410-2425. [CrossRef]

110. Ramsar Convention. Available online: https://www.ramsar.org/sites/default/files/documents/library/ info2007-01-e.pdf (accessed on 19 June 2020).

111. Wolanski, E.; Elliott, M. Estuar. Ecohydrology—An Introduction, 2nd ed.; Elsevier: Amsterdam, The Netherlands, 2016 ; p. 321.

112. Zedler, J.B.; Bonin, C.L.; Larkin, D.J.; Varty, A. Salt marshes. In Encyclopedia of Ecology; Jørgensen, S.E., Fath, B.D., Eds.; Elsevier, B.V. Radarweg: Amsterdam, The Netherlands, 2008; Volume 29, pp. 3132-3141.

113. Siddig, A.A.; Ellison, A.M.; Ochs, A.; Villar-Leeman, C.; Lau, M.K. How do ecologists select and use indicator species to monitor ecological change? Insights from 14 years of publication in Ecological Indicators. Ecol. Indic. 2016, 60, 223-230. [CrossRef]

114. Franco, A.; Franzoi, P.; Malavasi, S.; Riccato, F.; Torricelli, P.; Mainardi, D. Use of shallow water habitats by fish assemblages in a Mediterranean coastal lagoon. Estuar. Coast. Shelf Sci. 2006, 66, 67-83. [CrossRef]

115. Scapin, L.; Zucchetta, M.; Facca, C.; Sfriso, A.; Franzoi, P. Using fish assemblage to identify success criteria for seagrass habitat restoration. Web Ecol. 2016, 16, 33-36. [CrossRef]

116. Scapin, L.; Redolfi Bristol, S.; Cavraro, F.; Zucchetta, M.; Franzoi, P. Fish fauna in the Venice lagoon: Updating the species list and reviewing the functional classification. Ital. J. Freshw. Ichthyol. 2019, 5, 271-277.

117. Zucchetta, M.; Scapin, L.; Cavraro, F.; Pranovi, F.; Franco, A.; Franzoi, P. Can the Effects of Anthropogenic Pressures and Environmental Variability on Nekton Fauna Be Detected in Fishery Data? Insights from the Monitoring of the Artisanal Fishery Within the Venice Lagoon. Chesap. Sci. 2016, 39, 1164-1182. [CrossRef]

118. Cavraro, F.; Bettoso, N.; Zucchetta, M.; D'Aietti, A.; Faresi, L.; Franzoi, P. Body condition in fish as a tool to detect the effects of anthropogenic pressures in transitional waters. Aquat. Ecol. 2019, 53, 21-35. [CrossRef]

119. Franzoi, P.; Franco, A.; Torricelli, P. Fish assemblage diversity and dynamics in the Venice lagoon. Rend. Lincei 2010, 21, 269-281. [CrossRef]

120. Mosesso, P.; Angeletti, D.; Pepe, G.; Pretti, C.; Nascetti, G.; Bellacima, R.; Cimmaruta, R.; Jha, A.N. The use of cyprinodont fish, Aphanius fasciatus, as a sentinel organism to detect complex genotoxic mixtures in the coastal lagoon ecosystem. Mutat. Res. Toxicol. Environ. Mutagen. 2012, 742, 31-36. [CrossRef] [PubMed]

121. Kessabi, K.; Annabi, A.; Navarro, A.; Casado, M.; Hwas, Z.; Said, K.; Messaoudi, I.; Piña, B. Structural and molecular analysis of pollution-linked deformities in a natural Aphanius fasciatus (Valenciennes, 1821) population from the Tunisian coast. J. Environ. Monit. 2012, 14, 2254. [CrossRef] 
122. García-Oliva, M.; Marcos, C.; Umgiesser, G.; McKiver, W.; Ghezzo, M.; De Pascalis, F.; Pérez-Ruzafa, A. Modelling the impact of dredging inlets on the salinity and temperature regimes in coastal lagoons. Ocean Coast. Manag. 2019, 180, 104913. [CrossRef]

123. Ferrarin, C.; Ghezzo, M.; Umgiesser, G.; Tagliapietra, D.; Camatti, E.; Zaggia, L.; Sarretta, A. Assessing hydrological effects of human interventions on coastal systems: Numerical applications to the Venice Lagoon. Hydrol. Earth Syst. Sci. 2013, 17, 1733-1748. [CrossRef]

124. Lloret, J.; Marín, A.; Marín-Guirao, L. Is coastal lagoon eutrophication likely to be aggravated by global climate change? Estuar. Coast. Shelf Sci. 2008, 78, 403-412. [CrossRef]

125. Regulation (EU) 1143/2014. Available online: https://eur-lex.europa.eu/legal-content/EN/TXT/?qid= 1483614313362\&uri=CELEX:32014R1143 (accessed on 13 May 2020).

126. Global Invasive Species Database. Available online: http://www.iucngisd.org/gisd/100_worst.php (accessed on 4 December 2019).

127. Facca, C. Specie ittiche di interesse comunitario (allegato II della Direttiva 92/43/CEE) dell'habitat prioritario 1150* "Lagune costiere" del Mar Mediterraneo: Biologia, Gestione e Conservazione. In Proceedings of the 1st Level Professional Master in Wildlife Management, Venice, Italy, 4 December 2019. (In Italian)

(C) 2020 by the authors. Licensee MDPI, Basel, Switzerland. This article is an open access article distributed under the terms and conditions of the Creative Commons Attribution (CC BY) license (http://creativecommons.org/licenses/by/4.0/). 